\title{
György MARINKÁs* \\ Certain Aspects of the Agricultural Land Related Case Law of the European Court of Human Rights**
}

\section{Introduction}

The aim of the current article is to examine how the agricultural property is linked to other human rights in the case law of the European Court of Human Rights (hereafter: ECtHR) and the European Commission on Human Rights (hereafter: ECHR), ${ }^{1}$ which were established to interpret the European Convention on Human Rights ${ }^{2}$ (hereafter: Convention). Studying this topic can be regarded actual for two reasons: firstly, the institutions and bodies of the European Union, furthermore scholars and international institutions are involved in a - to say the least - vivid debate about the sustainability of the current market oriented regulation of the EU. Some argue that it would be better if the member states got larger space to manoeuvre, so they can decide on the conditions of trading in their arable lands? ${ }^{3}$ Secondly, at this very moment, the revision of the land regulation of the Central and Eastern European (hereafter: CEE) countries by the European Commission is in progress. The question is especially interesting in the light of the fact that the regulations of the CEE countries were based on the western member states' regulations. Regulations that European Commission or the European Court of Justice (hereafter: ECJ) found to be in conformity with the EU law during its earlier examinations, if examined the question at all. ${ }^{4}$

\footnotetext{
György Marinkás: Certain Aspects of the Agricultural Land Related Case Law of the European Court of Human Rights - Az Emberi Jogok Európai Bíróságának mezőgazdasági földekkel kapcsolatos ítélkezési gyakorlatának aspektusai. Journal of Agricultural and Environmental Law ISSN 1788-6171, 2018 Vol. XIII No. 24 pp. 99-134 doi: 10.21029/JAEL.2018.24.99

* dr. jur., PhD, assistant professor, University of Miskolc, Faculty of Law, Department of European Law and International Private Law, e-mail: joggyuri@uni-miskolc.hu

** This study has been written as part of the Ministry of Justice programme aiming to raise the standard of law education.

${ }^{1}$ Which was abolished in 1998 by Protocol 11 of the Convention.

2 European Convention on Human Rights (Rome, 4 November 1950).

${ }^{3}$ UN GA A/HRC/13/33/Add.2 report, 33; ECOSOC, NAT/632, Brussels, 21 January 2015; Directorate-General for Internal Policies of the Union: Extent of Farmland Grabbing in the EU, 2015; EP: Report on the state of play of farmland concentration in the EU: how to facilitate the access to land for farmers (2016/2141(INI)) A8-0119/2017); 2015 CEDR Potsdam Congress, Concluding Remarks, See: Szilágyi János Ede, Conclusions, Journal of Agricultural and Environmental Law (JAEL), 2015/19, 96-102; European Commission Interpretative Communication on the Acquisition of Farmland and European Union Law (2017/C 350/05).

4 Papik Orsolya: A Tagállamok birtokpolitikai mozgásterével kapcsolatos trendek, aktuális kérdések - Pódiumbeszélgetés, JAEL, 2017/22, 146-159, doi: 10.21029/JAEL.2017.22.132
} 
The current article is not intended to examine purely EU 5 or constitutional law related $^{6}$ questions in detail, as these topics are already processed in the writings of other authors. Instead, the main strive is a certain slice of the ECtHR. The author examined four types of cases regarding the agricultural lands: (i) compensation related cases, where the earlier proprietors' or their heirs' interests clashed with the interests of third parties, who acquired the property in good faith; (ii) the land consolidation issues; (iii) deprivation of property or the restriction of the use of property based on environmental protection considerations; and last, but not least (iv) those laws on inheriting agricultural lands, which pursue to prevent the agricultural land to be plotted into small pieces. These cases show the procedural guaranties that states have to obey, when they legislate on agricultural land and when they execute these laws.

The author believes that studying this part of the case law of the ECtHR can contribute to answer some questions which arose regarding the law of the EU on agricultural law, with special regard to the pending infringement proceeding, which aimed to examine the EU conformity of Section 108 of the Act No. CCXII of 2013 laying down certain provisions and transition rules in connection with Act No CXXII of 2013 concerning agricultural and forestry land trade (hereafter: Transitional Law), which contains certain provisions on the execution of Act No. CXXII of 2013 on agricultural and forestry land trade (hereafter: Land Trade Act). The above mentioned section abolished all contractual ususfructus rights on agricultural land on the $1^{\text {st }}$ of May 2014, in case the contracting parties were not close relatives.

The current article approaches the questions from two aspects: firstly, from the right to a fair trial and the right to an effective remedy as contained by Article 6 and 13 of the Convention, secondly from the aspect of the right to property as contained by Article 1 protocol No. $1^{7}$ to the Convention. Regarding the first one, the author is seeking to answer whether the Hungarian regulation, which is based on the statutory presumption that every single ususfructus established on agricultural land was created with the intention of circumventing the regulations and, which is - according to the Hungarian legislator - best remedied by an ex lege abolishment, excluding the judicial revision. Having some knowledge on the case law of the ECtHR, the author was sure even at the beginning of the current research that in a possible proceeding before the ECtHR, it

\footnotetext{
5 Andréka Tamás - Olajos István: A földforgalmi jogalkotás és jogalkalmazás végrehajtása kapcsán felmerült jogi problémák elemzése, Magyar Jog, 2017/7-8, 410-424; Raisz Anikó: Topical Issues of the Hungarian Land-Transfer Law Purchasing and Renting Agricultural Land: Legal Framework and Practical Problems, CEDR Journal of Rural Law, 2017/1, 68-74; Szilágyi János Ede: A magyar földforgalmi szabályozás új rezsimje és a határon átnyúló tulajdonszerzések, Miskolci Jogi Szemle, 2017/1 Special Edition, 107-124; Szilágyi János Ede: Az új tagállamok csatlakozási szerződései és a termőföldek tulajdonjogára vonatkozó nemzeti szabályozások, különösen a magyar jogi szabályozás, JAEL, 2010/9, 48.

${ }^{6}$ Olajos István: Az Alkotmánybíróság döntése a helyi földbizottságok szerepéről, döntéseiről, és az állásfoglalásuk indokainak megalapozottságáról, Jogesetek Magyarázata, 6/3, 17-32; Téglási András: Termőföldvédelem az Alkotmánybíróság gyakorlatában és az Alaptörvényben, in: Korom Ágoston (edit.): Az új magyar földforgalmi szabályozás az uniós jogban, Budapest, Nemzeti Közszolgálati Egyetem, 2013, 93-107.

${ }^{7}$ First Protocol to the ECHR (Paris, 20 March 1952).
} 


\section{György Marinkás \\ Certain Aspects of the Agricultural Land Related Case Law of the European Court of Human Rights}

Journal of Agricultural and

Environmental Law

$24 / 2018$

would find a breach of the right to a fair trial and the right to the effective remedy. It is worth mentioning that the advocate general of the ECJ - examining the case from the aspect of community law ${ }^{8}$ - already found the Hungarian regulation disproportional and nonconform with EU law. ${ }^{9}$

However the ECtHR provides a broad margin of appreciation for the member states regarding the shaping of their judicial review system, including the rules on public hearing; they cannot exclude the possibility of the judicial review of every single case as a whole. That is to say, ex lege abolishing every ususfructus contract, without the possibility of judicial review, in all probability would be considered disquieting.

While the author could place his examination on solid grounds regarding the right to a fair trial, in the case of the right to property - the other focal point of his examination -, he needed to rely on a less established point of view in the dogmatic ${ }^{10}$ of civil law. On the one hand, the author is totally aware that this part of the writing can easily attract criticism. The author did not find a perfect analogy - according to his best knowledge -, no precedent exist in any other state, which is part of the Convention. The Hungarian Constitutional Court (hereafter: HCC) in its decision 25/2015 (VII.21.) also contradicts the concept of ususfructus as property right: as it stated, the above mentioned regulation should not be judged by the rules of property deprivation, but instead by the rules on contract-law, which contain less strict rules compared to those on property. ${ }^{11}$

The only negligence found by the HCC was that the Hungarian Parliament failed to create the special rules, which are not governed by the Hungarian Civil Code, and which is to be applied in case of the final settlement between the contracting parties. ${ }^{12}$ As a result, certain costs and expenses are not reimbursed in the course of the final settlement between the former ususfructuaries and the proprietors.

On the other hand, contrary to the main strive, which is recorded in the resolution of the HCC, it is worth mentioning that - as Andréka Tamás writes - the 'ususfructus is a personal servitude, which provides certain proprietary rights to the beneficiary. ${ }^{13}$ It is most probably Sulyok Tamás, judge of the HCC, who in his parallel reasoning went the farthest stating that 'ususfructus established on a property can be regarded as a right in rem'. ${ }^{14}$

Presuming that the ususfructus can be regarded as a quasi-proprietary right, however, it means that it should be examined whether its deprivation is based on law, or pursues to a legal aim and is it can be regarded as proportional? The answer to the

\footnotetext{
8 The author, by citing the opinion of the advocate general does not intend to blur the lines between the community law, especially the case law of the ECJ and the ECtHR. He only wishes to point out that the provisions examined in the current study can face criticism on multiple platforms.

${ }_{9}^{9}$ ECJ, C-52/16 and C-113/16 SEGRO and Horváth joint cases, the opinion of advocate general Henrik Saugmandsgaard Øe, 31 Maj 2017, 92-97.

10 Special thanks for Mr. Leszkoven László for facilitating my research by providing consultations for me.

${ }^{11}$ HCC resolution no. 25/2015 (VII.21.), 53-66.

12 HCC resolution no. 25/2015 (VII.21.), 67.

13 Andréka - Olajos 2017, 417.

${ }^{14}$ HCC resolution no. 25/2015 (VII.21.), The parallel reasoning of judge Sulyok Tamás, 63.
} 
first question is obviously yes, but the latter two are harder to answer. Correcting the earlier mistakes made by the states - in this case the mistake of the Hungarian state that it established a regulation that was easy to be circumvented or even induced persons to do that ${ }^{15}$ - can be evaluated as a legitimate aim. Regarding proportionality it should be examined whether the compensation gained by the parties - if any -, was proportional to the deprived property? As mentioned above, the law does not cover any aspects of the final settlement and even those ususfructuaries, who concluded their contracts in good faith, cannot claim any compensation from the state.

The questions are asked, the answers are given by the below detailed cases.

\section{The case law of the ECtHR and the ECHR}

\subsection{Cases related to compensation}

The cases related to compensation were examined thoroughly by Raisz. Anikó, making valuable statements regarding the awkwardness of the ECtHR's case law in certain aspects. ${ }^{16}$

The current writing concerns the compensation cases, where the previously deprived lands or real-properties were acquired from the state or individuals by third parties, who acted in good faith; and where these third parties' proprietary rights were challenged by the former owners or their heirs. Having regarded the rather similar nature of the cases, the author dispenses with introducing every case in details.

In the Pincova $v$. Pinc case, ${ }^{17}$ the heir of the former proprietary of a confiscated house launched successful proceedings against the applicants in 1992. ${ }^{18}$ The applicants alleged the infringement of their property rights; since they concluded the contract in good faith and the national court did not grant them compensation proportionate to the value of the lost property. ${ }^{19}$

In the case at hand, the ECtHR found that the interference with the right to property amounted to 'deprivation of possessions' within the meaning of the second sentence of the first paragraph of Article 1 of Protocol No. 1. The Court reiterated its earlier case law and stated that the deprivation of property should be based on law, should pursue to a legitimate aim and should be proportionate, that is to say: it must strike a fair balance between the demands of the general interest of the community and the requirements of the protection of the individual's fundamental rights. In the present

\footnotetext{
15 Andréka - Olajos 2017, 417.

16 Raisz Anikó: A Beneš-dekrétumok által érintett tulajdoni kérdések az Emberi Jogok Európai Bírósága előtt, in: Horváth Attila - Korom Ágoston (edit.): Beneš-dekétumok az. Európai Parlamentben, Budapest, Nemzeti Közszolgálati Egyetem, 2014; Raisz Anikó, Földtulajdoni és földhasználati kérdések az emberi jogi bíróságok gyakorlatában, in: Csák Csilla (edit.): Az európai földszabályozás aktuális kihivásai, Miskolc, Novotni Alapítvány, 2010, 241-253.

17 ECtHR Pincová and Pinc v. Czech Republic, 5 November 2002 (36548/97).

18 Pincová and Pinc v. Czech Republic 2002, 9-32.

19 Pincová and Pinc $v$. Czech Republic 2002, 42.
} 


\section{György Marinkás \\ Certain Aspects of the Agricultural Land Related Case Law of the European Court of Human Rights}

Journal of Agricultural and

Environmental Law

$24 / 2018$

case even the applicants acknowledged that the state's acts were based on laws. ${ }^{20}$ Regarding the legitimate aim the Court reiterated its earlier findings in the James-case: ${ }^{21}$ Because of their direct knowledge of their society and its needs, the national authorities are in principle better placed than the international judge to appreciate what is in the public interest [...] unless that judgment is manifestly without reasonable foundation. ${ }^{22}$ Arising from this, the notion of 'public interest' is necessarily extensive. ${ }^{23}$ The Court examined weather the law succeeded in striking a fair balance between general interest of the community and the requirements of the protection of the individual's fundamental rights. In this regard the Court examined the extent of the compensation, which has to be reasonably related to market value of the lost property. On the other hand, legitimate objectives of 'public interest' may call for less than reimbursement of the full market value. Having regarded the fact that in the case at hand, compensation received by the parties' amounts to the $1 / 5$ of the current market value of the house, the state failed to strike the above mentioned fair balance, thus property rights were infringed. ${ }^{24}$

The joint cases under name Velikovi $2^{25}$ are worth highlighting since the applicants' situation is a bit similar to the ususfructuaries concerned by the Hungarian regulation, since the applicants were either proprietaries or long-term tenants. Furthermore, just like the rules of the Transitional Law, expect for a short period of time, the Bulgarian laws didn't provide compensation for the parties concerned. ${ }^{26}$ The ECtHR introduced the case law of the Bulgarian national courts in details, which in most cases declared the contracts concluded during the previous regime null and void on the ground of formal errors, ${ }^{27}$ and judged in favour of the persons looking for restitution. ${ }^{28}$ However, in the case under the name Velikovi, the ECtHR did not state the infringement of property rights in case the contract was declared null and void by the national courts and the applicants received any compensation from the state. ${ }^{29}$ The ECtHR in the course of evaluating the circumstances of the case ${ }^{30}$ referred to its former statements made in the Jahn and others vs. Germany case, according to which the Court considers it useful to reiterate certain special features of the present case and, in particular, the bistorical context in which it arose. ${ }^{31}$

In the Pyrantiená $v$. Lithuania case, ${ }^{32}$ which had a rather similar statement of facts as the previous cases, the Court came to the conclusion that a national regulation, which excludes the judical review of individial cases is contrary to the Convention. The

\footnotetext{
20 Pincová and Pinc v. Czech Republic 2002, 47-51.

${ }^{21}$ ECtHR, James and other vs the United Kingdom, 21 February 1986 (8793/79).

22 James and other vs the United Kingdom 1986, 46.

23 James and other vs the United Kingdom 1986, 46.

24 Pincová and Pinc v. Czech Republic 2002, 52-64.

${ }^{25}$ ECtHR, Velikovi and others vs. Bulgaria, 15 March 2007 (43278/98).

${ }^{26}$ Velikovi and others vs. Bulgaria 2007, 128-141.

${ }^{27}$ For example delegating rights contrary to statutory requirements.

28 Velikovi and others vs. Bulgaria 2007, 110-113; 117-120; 121-125.

${ }^{29}$ Velikovi and others vs. Bulgaria 2007, 194-200.

${ }^{30}$ Velikovi and others vs. Bulgaria 2007, 169.

${ }^{31}$ ECtHR, Jahn and others v. Germany, 30 June 2005 (46720/99, 72203/01 and 72552/01), 99.

32 ECtHR, Pyrantiená v. Lithuania, 12 November 2013 (45092/07).
} 
Court retairating its earlier jurisdiction - namely the Pincová case -, noted that remedying of old injuries does not create disproportionate new wrongs. To this end, the legislation should 'make it possible to take into account the particular circumstances of each case, so that individuals who have acquired their possessions in good faith are not made to bear the burden of responsibility, which is rightfully that of the State which has confiscated those possessions. ${ }^{33}$ The particular circumstances include - amongst others - 'the conditions under which the disputed property was acquired and the compensation that was received by the applicant in exchange for the property, as well as the applicant's personal and social situation'. ${ }^{34}$

In those cases, where the state deprived such persons from their property, who acquired their land or houses from another person and not directly from the state or state enterprise, which were directly involved in the deprivation, some particularly interesting questions arise. - True, however that sellers themselves bought the property in the previous regime from the state or such state enterpriese, which was directly involved in the nationalisation. - These type of cases were particularly common in Bulgaria.

In the Tomov and Nikolova vs. Bulgaria case, 35 the heirs of the formers owner filed a petition in 1991 to the local land commission requesting the restitution of the property confiscated by the previous regime. The local land commission granted their request on the $4^{\text {th }}$ April 1996. Subsequently the heirs alienated the land to Mr. K., who, in 2003, in order to actually come into possession, launched legal proceedings against the applicants, who acquired the property in good faith. The Supreme Court of Bulgaria found that the claims of those seeking for restitution should prevail over the claims of those, who acquired the property in good faith. ${ }^{36}$

The applicants alleged the infringement of their rights to property and the right to an effective remedy. The Court was of the view that examining the latter one is not necessary. ${ }^{37}$

Contrary to the state's point of view, the Court was of the view that the state is responsible for the situation, even if it did not participate directly in concluding the contracts at stake, since it was the state, which created such a legal environment, which provided primacy for the interests of the former owners or their heirs over the interests of those, who acquired the property in good faith. The ECtHR - amongst other reasons - saw no reason to set aside principles developed in the Velikovi-case. ${ }^{38}$ Just like in the Velikovi-case, the ECtHR noted that former eastern bloc countries were in special situation during their transition from socialist regimes into market oriented capitalist states with a democratic political regime and the Court evaluated this fact,

\footnotetext{
33 Pyrantiená v. Lithuania 2013, 50.

34 Pyrantiená v. Lithuania 2013, 51; Furthermore the ECtHR referred to the ECtHR, Mobylová

v. Caech Republic, 6 September 2005 (75115/01) case.

35 ECtHR, Tomov and Nikolova v. Bulgaria, 21 July 2016 (50506/09).

36 Tomov and Nikolova v. Bulgaria 2016, 6-12.

37 Tomov and Nikolova v. Bulgaria 2016, 20, 2.

38 Tomov and Nikolova v. Bulgaria 2016, 35, 4.
} 
when the above mentioned countries were concerned. ${ }^{39}$ This period for clemency applied only to the first years of the change of regime, however. The Bulgarian regulation at hand was inaugurated in 1997 - years after the change of regime -, which excluded the possibility of applying any clemency, mentioned above. Thus, the Court concluded that the Bulgarian law cannot be regarded as pursuing to a legitimate aim or, which conforms the requirement of legal certainty. ${ }^{40}$

In the Krasteva and others $v$. Bulgaria ${ }^{41}$ the statement of facts ${ }^{42}$ were almost identical to those of in the above introduced Tomov and Nikolova case. The similarity was apparent for the ECtHR too; therefore the Court asked the respondent state to provide statistical data on the similar cases tried before national court in a year. Based on the data provided by the respondent state, between 2010 and 2014, the courts of first instance heard approximately 35-50 cases. ${ }^{43}$ The applicants alleged the infringement of their right to property, the right to a fair trial, and the infringement of the prohibition of discrimination. The Court was of the view that it was sufficient to examine the complaints under the right to property. ${ }^{44}$

\subsection{Land Consolidation}

In the case law of the ECtHR, the land consolidation cases were to be found mainly related to Austria. The land consolidation procedure aims at defragmenting the fragmented agricultural lands by exchanging them in order to create economically better plot of lands. The procedure is based on the agreement of the concerned farmers and approved by authorities or conducted by the authorities. These procedures are complex and time consuming by their very nature, since the concerned plots are different in their extent and in their quality..$^{45}$ As a result it's almost 100\% sure that one or more farmers, who did not even want to participate - but were obliged by the authorities -, or those, who participated voluntarily, felt that the short end was given to them. In the complaints regarding the land consolidation the applicants either alleged the infringement of their right to property or the right to fair trial. The preceding was typically alleged because of the deprivation of the property of the applicants, without receiving proper compensation, while the latter one was asked because of the unreasonably long procedures or the dismissal of their request for an oral hearing.

The question of property rights is particularly interesting in the light of the provisions of the Austrian laws, which state that as a result of the land consolidation proceedings land owners loose ownership of their original plots of land with the

\footnotetext{
39 This meant that the Court left an even vaguer margin of appreciation for the states concerned with a change of regime regarding the restructuration of their society and economy.

40 Tomov and Nikolova v. Bulgaria 2016, 43, 44, 48, 51, 54-55.

${ }^{41}$ ECtHR, Krasteva and others v. Bulgaria, 1 June 2017 (5334/11).

42 Krasteva and others v. Bulgaria 2017, 5-10.

43 Krasteva and others v. Bulgaria 2017, 20-23.

${ }^{44}$ Krasteva and others v. Bulgaria 2017, 17-18, 22-30.

45 The possible internal water and the amount of sunny hours are of paramount interest.
} 
provisional transfer. ${ }^{46}$ Thus, based on the case law of the ECtHR ${ }^{47}$ those lands can no longer be considered as a 'possession' within the meaning of Article 1 of Protocol No. 1. Furthermore - as the Court notes -, 'where the law makes it clear that possible changes in value which arise after the provisional transfer are not to be taken into account, no legitimate expectation arises',48 which could be evaluated as possession under certain circumstances. ${ }^{49}$ Having considered the above mentioned, in certain cases the ECtHR rejected to examine the application under Article 1 of Protocol No.1.50

In the Erkner and Hofauer v. Austria case ${ }^{51}$ the applicants did not show up at the hearing despite the notice of the authorities. As a result, decision was made in their absence. In the same year they attended another hearing with their attorney and asked for the renegotiation of the land consolidation plan as far as it concerned their plot of land, since the new plot, which was offered them was of worse quality, over-shadowed and laid far from their place of residence. The authorities dismissed the request. ${ }^{52}$

The applicants alleged the infringement of Article 6, 8, 14 and Article 1 of Protocol No.1. The Commission was of the view that it was sufficient to examine the complaints under Article 6 and Article 1 of Protocol 1.

The Court first examined the alleged infringement of Article 6 in merits. Reiterating its earlier case law, the Court noted that in civil proceedings, the 'reasonable time' normally begins to run from the moment the action was instituted before the 'tribunal' 53 - as it was the case in the case at hand -, in certain cases, however it could be an earlier date. ${ }^{54}$ Also, referring to its earlier case law ${ }^{55}$ the court reiterated that the reasonableness of the length of proceedings is to be assessed regarded the (i) complexity of the case; (ii) the applicants' behaviour and the (iii) conduct of the relevant authorities. Although the complex nature of the case at hand - having regarded the fact that by the end it concerned 38 owners - was beyond question, a procedure, which lasted for 16.5 years, cannot be considered as concluded within a reasonable time. ${ }^{56}$

Regarding the right to property, the Court came to the conclusion that it was the right to the 'peaceful enjoyment of property' - first sentence of the first paragraph of Article 1 of Protocol No.1 -, which was infringed, since neither de jure nor de facto

\footnotetext{
46 See: ECtHR, Prischl v. Austria, 27 April 2007 (2881/04), 35-37.

${ }^{47}$ ECtHR, Marckx v. Belgium, 13 June 1979 (6833/74), 50.

${ }^{48}$ ECtHR, Kolb and others v. Austria, 21 February 2002 (35021/97) (45774/99).

${ }^{49}$ ECHR, A, B, C, D, E, F, G, H and I v. the Federal Republic of Germany, 16 July 1976 (5573/72 and 5670/72), DR 7, 8; ECHR, Consorts D. v. Belgium, 18 December 1988 (11966/86).

${ }^{50}$ Prischl v. Austria, 2007.

${ }^{51}$ ECtHR, Erkner and Hofauer v. Austria, 24 March 1987 (9616/81), merits.

${ }^{52}$ Erkner and Hofauer v. Austria 1987, 8-36.

${ }^{53}$ ECtHR, Kern v. Austria, 24 February 2005 (14206/02), 51; Kolb, Op. cit. 49; ECtHR, Wiesinger v. Austria, 30 October 1991, 52; ECtHR, Deumeland v. The Federal Republic of Germany, 29 May 1986 (9384/81), 77.

${ }^{54}$ ECtHR, Golder v. the United Kingdom, 21 February (4451/70), 32.

55 Amongst others: ECtHR, Frydlender v. France, 27 June 2000 (30979/96), 43; Wiesinger Op. cit. 54; ECtHR, Zimmermann and Steiner v. Switzerland, 13 July 1983 (8737/79), 66; ECtHR, Buchbolz v. Federal Republic of Germany, 6 May 1981 (7759/77), 49.

${ }^{56}$ Erkner and Hofauer v. Austria 1987, 63-70.
} 
deprivation took place. ${ }^{57}$ Regarding the fair balance between the public interest and the individual rights, the Court stated that the procedure lasted for 16.5 years. Although the government held that the length of the procedure cannot be examined under the right of the property, the Court reminded that based on its earlier case law, 58 'one and the same fact may fall foul of more than one provision of the Convention and Protocols.' That is to say they are interchangeable with each other. The Court, after having examined all the relevant circumstances of the fact, came to the conclusion that the authorities did not reach the necessary fair balance between public interest and individual rights. ${ }^{59}$

In the Ernst and Anna Lughofer v. Austria case ${ }^{60}$ the Austrian authorities instituted land consolidation proceedings in 1973, and in the course of the proceedings a public hearing was held. As a result of the proceedings, the authorities issued a land consolidation plan, which was appealed by the applicants on the ground that they did not receive a fair compensation. ${ }^{61}$ The applicants alleged the infringement of Article 6, as the administrative court dismissed their claim for a public hearing. The ECHR shared the applicants view and even the state admitted the fact of infringement. Having regarded these facts and its own earlier case law, Court found a breach of Paragraph (1) Article 6.62

In the Walder v. Austria case, 63 the applicant alleged the infringement of the right to fair trial, since the length of the proceedings was beyond reasonable. The Court like in the similar previous cases stated the complex nature of such proceedings and the aspects to be examined in such cases and found that the right to a fair trial was infringed. ${ }^{6}$

In the Prischl v. Austria case the applicant alleged that her lands are more valuable than they were estimated earlier and that her late husband did not receive a proper compensation in turn for his plots. Based on these circumstances, she alleged the infringement of her property rights. ${ }^{65}$ On the other hand, the applicant primarily alleged the infringement of her right to a fair trial, based on the fact that the length of the proceedings were contrary to the requirement of reasonable time and the national courts rejected her request for a public hearing. ${ }^{66}$

Regarding the alleged infringement of Article 6, the Court was of the view that it was sufficient to examine the length of the proceeding and dismissed the other two complaints. The Court pointed out the fact that based on its case law the land reform committees are considered as courts, thus a public hearing held by such committees can be regarded as a hearing by a national court. ${ }^{67}$ Thus the alleged infringement did not occur.

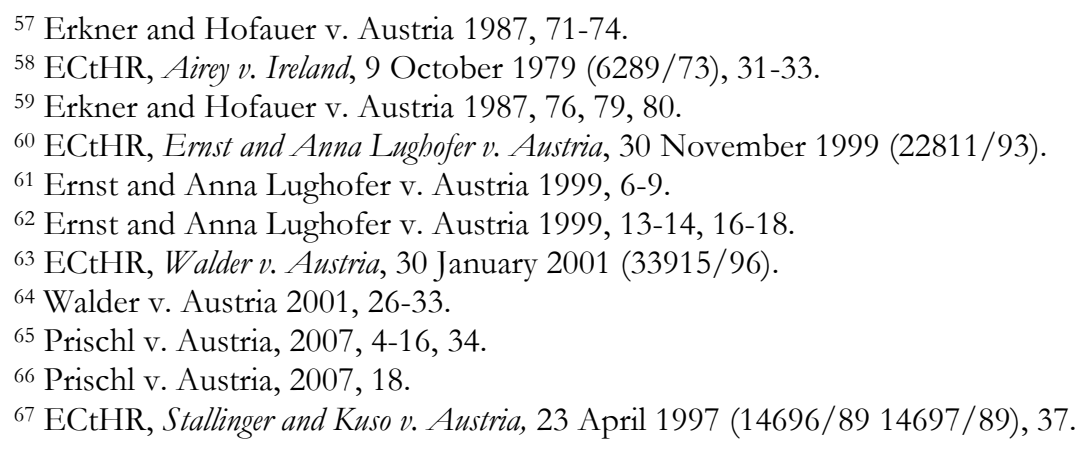


Regarding the applicant's allegation that the procedure was not fair, the ECtHR reiterated that based on its case law $^{68}$ the procedure of the national authorities and the courts can only be subject of examination by the ECtHR in case the procedure infringes a right protected under the Convention. The Convention however does not contain any provision on the rules of evidence of the national courts, e.g. what should be considered admissible and how it should be evaluated. Regarding the length of the proceedings the Court reiterated the aspects to be examined as in its earlier cases. Having regarded all the circumstances of the case, the Court found the infringement of Paragraph (1) of Article $6 .{ }^{69}$

Regarding the alleged infringement of the right to property, the Court reiterated ${ }^{70}$ that the applicant did not have a right to property, which could have fallen under the Convention and thus refused to examine the application in this regard. ${ }^{71}$

In the Ortner $v$. Austria case ${ }^{72}$ the applicant alleged the infringement of the right to fair trial, and the right to property. The preceding was requested by the applicants, since the case was tried beyond reasonable time. In the similar cases ${ }^{73}$ the Court was prone to find the infringement that the cases were beyond reasonable time. In the present case, the statement of facts were rather complex, ${ }^{74}$ and having regarded all the circumstances of the case, the length of procedure was beyond reasonable time, thus the Court found infringement of Article $6 .{ }^{75}$

The Court refused to examine the infringement of the right to property for two reasons: firstly, the applicant failed to prove that he had to bear a disproportional burden, and secondly, the length of the procedure in itself does not suffice to state the infringement of the right to property. ${ }^{76}$

\subsection{Environment protection}

In the Matos e Silva ${ }^{77}$ case the crucial question was, whether the Matos e Silva a company registered under the Spanish laws - had property rights on the plot of land, which was the subject of the case. The company cultivated the plot, which was given into concession by a royal decree issued in 1884 and, which was bought by the company in 1899 from the original beneficiary of the concession. This fact was recorded in the land registry. Still, the royal decree granted the right to the state to take back the plot without any compensation. Accordingly, when the state created an environmental protection zone in 1978, did not grant any compensation for the

\footnotetext{
${ }^{68}$ ECtHR, García Ruiz v. Spain, 21 January 1999 (30544/96), 28.

${ }^{69}$ García Ruiz v. Spain 1999, 21, 24, 29-33.

${ }^{70}$ As it was written in the introduction of the current sub-section.

71 Prischl v. Austria, 2007, 35-37.

72 ECtHR, Ortner v. Austria, 31 May 2007 (2884/04).

73 See the Kolb and others case!

${ }^{74}$ Like in the Wiesinger case, 55.

75 Ortner v. Austria, 2007, 21-23, 30-34.

76 Ortner v. Austria, 2007, 36-37.

${ }^{77}$ EJEB, Matos e Silva Lda. and other v. Portugal, 16 September 1996 (15777/89).
} 
company. The state was of the view that based on the 1884 decree the state withdrew the concession and did not expropriate the property. ${ }^{78}$

The applicants alleged the infringement of Section (1) Article 6 of the Convention based on the unreasonable length of the proceeding and the infringement of the right to an effective remedy (Article 13 of the Convention). In their view, the state failed to provide the latter one. Furthermore, they alleged the infringement of Article 1 of Protocol No.1 and the infringement of Article 14 taken in conjunction with Article 1 of Protocol No.1.79

Regarding the infringement of Article 6 and 13, the Court took the view that the unreasonable length of the proceedings does not concern the access to tribunal. The difficulties encountered by the applicants should be judged under the conduct of the authorities and their right to access those remedies. Since the applicants were able to institute proceedings the right under Article 13 was not infringed. Having examined the length of the procedure, the court found the infringement of Paragraph (1) of Article 6.80

As mentioned earlier, the core issue of the case was the property right of the applicants: the state was of the view that applicants could not allege the infringement of property rights, since the plot had never been their property. The state did not expropriate the plot, only withdrew a concession. Moreover the state contested the Court's jurisdiction to decide whether or not a right of property exists under domestic law. The applicants argued the fact that their ownership title was registered in the land registry in 1899, and that the state authorities had always regarded Matos e Silva as owner of the land proves the existence of their property rights. ${ }^{81}$

The ECtHR took the view that the applicants' argument is correct; they can be regarded as the owners of the plot. ${ }^{82}$ Regarding the other argument of the state - which contested the Court's right to decide on the ownership title of the applicants -, the Court reiterated its case law, and noted that the notion of possession has an autonomous meaning. ${ }^{83}$

Subsequently the ECtHR determined that in the case at hand it was the right to peaceful enjoyment of property, which was infringed. Regarding the fair balance between the public interest and the individual rights, the Court came to the conclusion that having regarded the length of the proceedings and the uncertainty, what the applicants had to bear in connection with losing their property and the possible compensation, the state failed to strike a fair balance between them. Thus the Court found the breach of the right to property. Regarding the alleged infringement of Article 14 it was of the view that it was not necessary to examine the case under this head. ${ }^{84}$

\footnotetext{
${ }_{78}$ Matos e Silva Lda. and other v. Portugal 1996, 10-45.

${ }^{79}$ Matos e Silva Lda. and other v. Portugal 1996, 54.

80 Matos e Silva Lda. and other v. Portugal 1996, 60-70.

${ }^{81}$ Matos e Silva Lda. and other v. Portugal 1996, 72-73, 75, 77.

82 Matos e Silva Lda. and other v. Portugal 1996, 74-75.

${ }^{83}$ ECtHR, Gasus Dosier- und Fördertechnik GmbH v. the Netherlands, 23 February 1995 (15375/89), 46.

${ }^{84}$ Gasus Dosier- und Fördertechnik GmbH v. the Netherlands 1995, 86-93, 96.
} 


\section{György Marinkás \\ Certain Aspects of the Agricultural Land Related Case Law of the European Court of Human Rights}

Journal of Agricultural and

Environmental Law

$24 / 2018$

In the Schelling $v$. Austria case ${ }^{85}$ the applicant wanted to lay down a culvert through a drain, on his agricultural land, which was under cultivation at the time. The applicant requested the approval of the competent authorities, which after an oral hearing, dismissed his request. The domestic courts consistently refused to hold oral hearings. Having regarded this fact, the applicant alleged the infringement of Paragraph (1) of Article 6.86

The ECtHR was of the view that courts have every right to abstain from holding a public hearing if it is necessary for the effective and economic conduction of the procedures, ${ }^{87}$ and where proceedings concerned exclusively legal or highly technical questions, ${ }^{88}$ which can be clarified by experts and not by the public. In the present case however, the Court did not find that any of these circumstances would stand and therefore found the infringement of Section (1) of Article 6.89

In the Barcza and others $v$. Hungary case,${ }^{90}$ the applicants possessed an agricultural plot, which based on a decision - became effective on the 16 December 2002 - of the administrative authorities, became part of a newly established environmental protection area. The decision ruled on the expropriation and obliged the state to make an offer on the compensation for the applicants. Since the state failed to fulfil its obligation to expropriate the land and compensate the applicants, they offered their lands for sale for the state multiple times. The authorities did not take the offer. The case was ended by the local government office, which determined the amount of compensation in 31.170.000 Ft, that is to say $126.000 €$. The applicants received the amount in the next year. ${ }^{11}$

The applicants complained that their right to peaceful enjoyment of possessions had been violated because the domestic authorities continuingly failed to settle the expropriation and as a result they were unable to make use of their property. The state contested the applicants stand as a victim, arguing that the statement of facts invoke Paragraph (1) of Article 6, because - amongst other facts - the applicants did receive compensation. Contrary to the Brumăresci ${ }^{92}$ and Jasiuniene $e^{93}$ cases, where the applicants did not receive compensation, thus the ECtHR found that both the right to a fair trial and the right to the property were violated. ${ }^{94}$ The Court reiterated its own

\footnotetext{
${ }^{85}$ ECtHR, Schelling v. Austria, 10 November 2005 (55193/00).

${ }^{86}$ Schelling v. Austria 2005, 8-25, 26.

${ }^{87}$ See the earlier mentioned Prischl case, where the Court come to the view that the oral hearing held by the administrative bodies constituted enough procedural guarantee.

${ }^{88}$ Furthermore: ECtHR, Döry v. Sweden, 12 November 2002 (28394/95), 42-43; ECtHR, Speil v. Austria, 5 September 2002 (42057/98); ECtHR, Varela Assalino v. Portugal, 25 April 2002 (64336/01); ECtHR, Schuler-Zgraggen v. Switzerland, 24 June 1993 (14518/89), 58.

${ }^{89}$ Schelling v. Austria 2005, 29-33.

${ }^{90}$ ECtHR, Barcza and other v. Hungary, 11 October 2016 (50811/10).

${ }^{91}$ Barcza and other v. Hungary 2016, 5-22.

92 ECtHR, Brumărescu v. Romania, 28 October 1999 (28342/95).

${ }^{93}$ ECtHR, Jasiūnienè v. Lithuania, 6 March 2003 (41510/98).

${ }^{94}$ Barcza and other v. Hungary 2016, 28.
} 
earlier case law $^{95}$ and came to the conclusion that 'a decision or measure favourable to the applicant is not in principle sufficient to deprive him or her of victim status unless the national authorities have acknowledged, either expressly or in substance, and then afforded redress for, the breach of the Convention. ${ }^{\text {'t }}$

Regarding the nature of expropriation of property, the applicants were of the view that they were hindered in disposing over their property, the state argued that de facto expropriation took place, while the ECtHR having regarded all the relevant facts of the case, concluded that applicants were hindered in the peaceful enjoyment of their property. Subsequently the Court examined whether the state stroke a fair balance between public interest and the individual rights of the applicants. The Court was of the view that having considered the uncertainty that the applicants had to suffer for years and that the applicants did not have a realistic chance to sell the property or obtain a just compensation, the right to property was breached. ${ }^{97}$

In the Tumeliai $v$. Lithuania case ${ }^{98}$ just like in the previous case, the applicants' plot of land was declared to be a natural protection area, which resulted in the restriction of their right to dispose over it. The case started, when the authorities ordered the demolition of the applicants' building, which was built illegally in the view of the authorities. The applicants claimed that the building was constructed according to the laws. ${ }^{99}$ The applicants alleged the infringement of their right to property and fair trial, since the principle of legal certainty was not respected by state authorities. The Court was of the view that it was sufficient to examine the case at hand under the alleged infringement of the right to property. ${ }^{100}$

The state argued that the applicants did not have a property right or any legitimate claim to property right within the meaning of Article 1 of Protocol No. 1, since the case law of the country's constitutional court does not recognise property rights over illegally obtained property. The ECtHR came to the opposite conclusion from the very same case law, stating that illegally obtained property too, is entitled for protection. ${ }^{101}$

The ECtHR highlighted the important nature of environment protection in several cases. ${ }^{102}$ Notwithstanding the state is still obliged to strike a fair balance between the public interest and the individual rights. ${ }^{103}$ At the case at hand, the Court evaluated the interference as the restriction of the applicants' 'right to dispose over their property.' The decision of the authorities was based on law, and pursued public interest

\footnotetext{
95 ECtHR Dalban v. Romania, 28 September 1999 (28114/95), 44; ECtHR, Konstantin Markin v. Russian Federation, 22 March 2012 (30078/06), 82.

${ }_{96}$ Barcza and other v. Hungary 2016, 31-38.

97 Barcza and other v. Hungary 2016, 39-48.

${ }^{98}$ ECtHR, Tumeliai v. Lithuania, 9 January 2018 (25545/14).

99 Tumeliai v. Lithuania 2018, 5-23.

100 Tumeliai v. Lithuania 2018, 58, 83-85.

101 Tumeliai v. Lithuania 2018, 59-66.

102 ECtHR, Depalle v. France, 29 March 2010 (34044/02), 81; ECtHR, Turgut and others v. Turkey, 8 July 2008 (1411/03), 90; ECtHR, Köktepe v. Turkey, 22 July 2008 (35785/03), 87; ECtHR, Șatır v. Turkey, 10 March 2009 (36192/03), 33.

103 ECtHR, Vistins s and Perepjolkins v. Lithuania, 25 October 2012 (71243/01), 109.
} 
- environment protection -, thus the only question to be determined was whether it was proportionate or not. ${ }^{104}$ In this regard the Court, referred to its earlier case law, ${ }^{105}$ and took the view that in the case at hand the authorities, while correcting their earlier mistakes put striking and disproportionate burden on the applicants. Thus the Court found the right to property was infringed. ${ }^{106}$

\subsection{Inheritance}

Many EU member states have a legal prescription on the minimum size of agricultural land, which - amongst other solutions ${ }^{107}$ - is secured by that in case of multiple heirs to a farm, only one of them can be the principle heir, who takes over the farm and pays off the others. The principle heir is generally the elder and/or the one with appropriate qualification. These legal prescriptions restrict the right to acquire property, which is not protected by the Convention based on the case law of the ECtHR; ${ }^{108}$ on the other hand it raises some interesting question from the view of constitutional law. ${ }^{109}$

In the Inze v. Austria case ${ }^{110}$ the applicant inherited a farm alongside with his siblings. Subsequently the applicant submitted a request to the authorities - as required by Austrian laws - to point him as the principle heir, as the elder and the one, who has the necessary qualifications. The applicant intended to pay off the other heirs. Furthermore he stated that the other heirs do not have the necessary qualification, which excludes them from inheriting an agricultural land according to Austrian laws. The authorities dismissed his claim based on the then applicable laws, which gave preference to legitimate child over illegitimate child. Furthermore, an expert asked by the authorities held that the applicant's sister had the necessary qualification to take over the farm. Since the applicant failed before the national courts too, he agreed to sign a deal, which was rather disadvantageous for him. ${ }^{111}$

The applicant claimed that he was discriminated against; when the authorities denied pointing him out as the principle heir because of his status as illegitimate child.

\footnotetext{
104 Tumeliai v. Lithuania 2018, 73-76.

105 ECtHR, Romankevič v. Lithuania, 2 December 2014, (25747/07), 38-39; ECtHR, Albergas and Arlauskas v. Lithuania, 27 May 2014, (17978/05), 59.

106 Tumeliai v. Lithuania 2018, 77, 80, 82.

107 Bányai Krisztina: A Földszerzés korlátozása Nyugat-Európában, Miskolci Jogi Szemle, 2017/2 (special edition), 71-80.

${ }_{108}$ Having regarded that the Convention - contrary to the former Hungarian Constitution and the Basic Law in effect does not refer to the right of inheriting, it does not appear in the case law of the ECtHR independently. In some cases however, where the Court concerned the right to inherit in conjunction with a right protected by the Convention or its Protocols. See the Marckx case!

109 The already HCC resolution 5/2016 AB (III.1.) concerned the parallels between the right to inherit and the right to property both in the majority opinion and the parallel reasoning of judge Tamás Sulyok.

110 ECtHR, Inze v. Austria, 28 October 1987 (8695/79).

111 Inze v. Austria 1987, 8-24, 25.
} 
Having regarded this fact, he alleged the infringement of Article 14 of the Convention which prohibits discrimination - in conjunction with the infringement of his property rights. ${ }^{112}$

The state contested the applicant's stand as a victim, since he already received compensation. The ECtHR on the other hand alongside with the applicant and the ECHR was of the view that the applicant was not in the proper position to make a fair deal, when he signed the above mentioned agreement. Actually he acted out of necessity. ${ }^{113}$ Furthermore the state contested the applicant's right to property: in its view just like in the Marckx case ${ }^{114}$ the applicant did not own a property right or legitimate expectation to property right, 115 thus no infringement of right occurred. The ECtHR however was of the view that in the case at hand, - contrary to the Marckx case, where the applicant alleged the infringement in an abstract manner ${ }^{116}$ - the applicant had already acquired a right to a share of his deceased mother's estate by inheriting it. ${ }^{117}$

As the Court pointed out, based on its earlier case law, the infringement of Article 14 can only be stated if the difference of treatment 'has no objective and reasonable justification', that is to say, if it does not pursue a 'legitimate aim' or if there is not a 'reasonable relationship of proportionality between the means employed and the aim sought to be realised'. In this regard the states own a vague margin of appreciation, the limits of which is determined by the circumstances and the subject of the case. ${ }^{118}$ At the same time the Court noted that the Convention is a living instrument to be interpreted in the light of present-day conditions. Having regarded the above mentioned, in the present case the Court did not accept the state's out of date argument on the possible causes of preferring legitimate child over illegitimate child in case of rural population. Thus, the Court found the infringement of Article 14 in conjunction with the infringement of Article 1 of Protocol $1 .{ }^{119}$

In the Osinger $v$. Austria case $e^{120}$ too, both the applicant and his sister asked to be pointed as the principle heir of a farm. ${ }^{121}$ The applicant alleged the infringement of his right to a fair trial, since the Austrian authorities dismissed his request for a public hearing. ${ }^{122}$

The state argued that in the hereditary procedures the exclusion of the general public is necessary in order to protect the private life of the parties as contained by

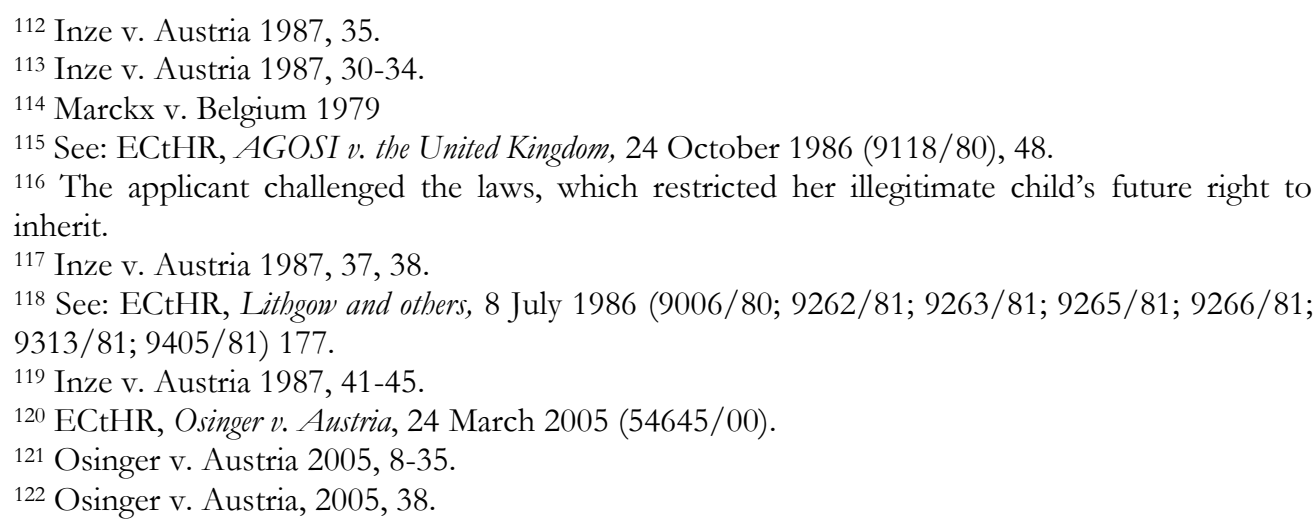


Article 8 of the Convention - 'Right to respect for private and family life' - , since the family relations and the pecuniary issues of the parties are none of the general public's concern. Referring to the earlier case law of the ECtHR ${ }^{123}$ the state argues that deciding on such a technical question - like the hereditary nature of a farm -, can be judged without holding a public hearing. The ECtHR, while acknowledged that the above argument is legitimate, reiterated that based on its case law, ${ }^{124}$ publicity is one of the main guarantees of fair trial, which provides the control of society above the procedures of the state organs. It is fact that the Court's case law allows the states to exempt certain cases; ${ }^{125}$ the ECtHR however still reserves the right, ${ }^{126}$ to supervise such national rules. In the present case, the ECtHR was not satisfied with the state's argument, that in the case at hand, just like in the Schuler-Zgraggen v. Switzerland case ${ }^{127}$ it was only a question technical nature, which was needed to be clarified and accordingly found the infringement of the right to a fair trial because of the lack of public hearing. ${ }^{128}$

\section{Summary}

The author of the current article sought to the answer whether Section 108 of the Transitional Law is in conformity with the Convention from the perspective of the right to a fair trial, the right to an affective remedy and the right to property.

According to the permanent case law of the ECtHR regarding the right to a fair trial, the states enjoy a wide margin of appreciation regarding the rules of judicial review and the kind of evidence they require. In the land consolidation and environment protection cases the denial of holding a public hearing was a rather common complaint. The Court reiterated that according to its case law - amongst others in the Stallinger and Kuso - case, the land commissions can be regarded as courts and since they hold public hearings, there is no need for a public hearing held by the domestic courts. Furthermore, the oral hearing can be dismissed in case, when answering the question at stake requires high technical qualification or it is necessary to answer a complicated legal question as it occurred in the Schelling case, which was introduced among the environment protection cases. A regulation however, which categorically excludes judicial revision - as it was put into record amongst others in the Pyrantiená case contraradicts the Convention.

In the land consolidation cases the other typical complaint was the unreasonable length of the procedures as some of the procedures lasted for a decade or

\footnotetext{
123 ECtHR, Varela Assalino v. Portugalia, 25 April 2002 (643369/01).

124 ECtHR, Sutter v. Switzerland, 22 February 1984 (8209/78), 26.

125 In the particular case the Court accepted the state's argument that in case of dangerous criminals providing publicity requires disproportional efforts from the state on the field of maintaining security. See: ECtHR Campbell and Fell v. the United Kingdom, 28 June1984 (7819/77 7878/77), 87-88.

126 ECtHR, Riepan v. Austria, 14 November 2000 (35115/97), 34.

127 ECtHR, Schuler-Zgraggen v. Switzerland, 24 June 1993 (14518/89).

128 Osinger v. Austria 2005, 39, 43-44, 47, 49, 51, 53.
} 
even longer. The court based on its case law examines three aspects in this regard: (i) the complexity of the case; (ii) the applicants' behaviour and the (iii) conduct of the relevant authorities. While land consolidation procedures are complex and time consuming by their very nature, in most cases the Court found the infringement of the right to a fair trial as that their length was beyond reasonable time.

Summarizing the above, it can be concluded that in the land consolidation cases, the applicants typically alleged the infringement of their right to a fair trial. The infringement of the right to property was alleged only secondarily in nature, typically because of the insufficient amount of compensation received. Moreover, the ECtHR in itself found it unnecessary to examine the cases under the right to property. At the same time, it occurred that the Court examined the length of the proceedings under the property rights, instead of the right to a fair trial as the Courts case law - Airey case states: 'one and the same fact may fall foul of more than one provision of the Convention and Protocols' That is to say they are interchangeable with each other.

The permanent case law of the ECtHR - which was brought into prominence in the compensation and hereditary related cases -, requires that the expropriation must be based on law, to pursue a legitimate aim and has to be proportionate. Public interest for example can be regarded as a legitimate aim, regarding of which, the state legislatures enjoy a vague margin of appreciation as stated in the James case. Moreover, the former eastern bloc countries were in special situation and enjoyed an even wider margin of appreciation as noted in the Jahn case by the ECtHR.

Public interest is necessarily a vague notion, which can include the correcting of mistakes committed by the state earlier, e.g. providing compensation for those - or their heirs -, who were deprived of their property after the Second World War. Based on the case law of the Court however, remedying of old injuries does not create disproportionate new wrongs as it was stated in the Pincová case.

Preventing the fragmentation of agricultural plots through state legislation, which allows only one heir - most probably the eldest and the one, who has the necessary qualification - can be regarded as pursuing to public interest. Actually, Austrian laws restrict the right of the heirs without the necessary qualification to acquire agricultural property. This regulation is in conformity with the Convention as far as it's not discriminatory like the Inze case, and the rules of a fair trial are held, like in the Osinger case.

Examining the proportionality of the deprivation of property, the amount of compensation received by the applicants is of paramount nature, which on the one hand has to be reasonably related to market value of the lost property, on the other hand legitimate objectives of 'public interest' may call for less than reimbursement of the full market value as it was stated in the Pincová case.

The question to be answered after studying the case law of the ECtHR is whether the Hungarian regulation, namely Section 108 of the Transitional Law is in conformity with the Convention. The author of the current article firmly believes that from the point of the right to a fair trial it is surly against the convention, while from the aspect of the right to property, it is most probably against it. - On condition that the presumption introduced in the first chapter is accepted. 
Regarding the right to a fair trial, the Hungarian regulation, by ex lege abolishing every ususfructus contract on agricultural land based on a statutory presumption namely that every ususfructus contract was concluded in order to circumvent the law -, and excluding the judicial review of the cases on a one by one basis is contrary to the rights of fair trial and effective remedy even if state legislations enjoy a wide margin of appreciation as it was stated in the Pyrantiená case.

Regarding the right to property it has to be examined whether the act of the state authorities is based on the law, pursue to a legitimate aim - e.g. public interest and is it proportionate? The answer to the first question is clear: it is based on the law. The answers to the other two questions are not that easy, however. While the abolishment of contracts, which were concluded contrary to the law, with the intention of circumventing the laws, can be regarded as pursuing legitimate aim, public interest, the method chosen by the state is disproportionate to the aim to be achieved as it affects those parties too, who acted in a good faith. As a result remedying of old injuries create disproportionate new wrongs, which is against the Convention as it was stated in the Pincová case. Furthemrore, it has to be noted that - as it was stated in the Tumeliai case -, illegally obtained property too, could enjoy statutory protection. Thus, ususfructus contract aiming at circumventing laws can enjoy some kind of protection too, even if it's not fair based on a natural sense of justice.

Going further with these thoughts, from the aspect of proportionality it should be examined how the compensaton received compares to the market value of the lost property as it was stated in the Pincová case. The HCC in its resolution 25/2015 (VII.21.) found that the fact that the Hungarian Parliament failed to create the special rules which are to be applied in case of the final settlement between the contracting parties, where the general rules of the Hungarian Civil Code cannot be applied is contrary to the Basic Law of Hungary. As a result, certain costs and expenses are not reimbursed in the course of the final settlement between the former ususfructuaries and the proprietors.

One should keep in mind however that in the land consolidation cases, the ECtHR - in case the parties alleged at all - either refused to examine the violation of property right arguing that based on Austrian laws the parties did not have a property right, like in the Prischl case, or examined the infringement of property right under the length of the procedure as in the Erkner case. In a third instance - the Ortner case the Court did not examine it arguing that stating the violation of the right to a fair trial in itself constitutes a just satisfaction.

The question whether the ECtHR would examine a Hungarian case possibly brought before it under the right to property or only under the right to fair trial is still waiting to be answered. 


\section{MARINKÁs György* \\ Az Emberi Jogok Európai Bíróságának mezőgazdasági földekkel kapcsolatos ítélkezési gyakorlatának aspektusai**}

\section{Alapvetés}

Jelen írás célja megvizsgálni, hogy a mezőgazdasági földtulajdon mely emberi jogok vonatkozásában jelenik meg az Emberi Jogok Európai Egyezményét (a továbbiakban: EJEE) értelmezni hivatott Emberi Jogok Európai Bírósága (a továbbiakban: EJEB), illetve az Emberi Jogok Európai Bizottsága (EJEBiz)² joggyakorlatában. E kérdés vizsgálata két okból kifolyólag tekinthető aktuálisnak: egyrésžt, az Európai Unió intézményei és szervei, valamint a témával foglalkozó szakértők és nemzetközi szervezetek jelenleg is finoman fogalmazva - élénk vitát folytatnak arról, hogy a hatályos - piaci jellegú uniós szabályozás megfelelő-e? Avagy az alapszabadságok feltétlen érvényesülése helyett érdemesebb lenne-e nagyobb mozgásteret biztosítani a tagállamoknak, hogy eldönthessék milyen feltételek mellett bocsátható forgalomba a saját termőföld vagyonuk?3 Másrésærôll, jelenleg is folyamatban van a közép-kelet-európai országok földforgalmi rezsimjeinek az Európai Bizottság általi vizsgálata. - Különösen érdekessé teszi a kérdést, hogy e földforgalmi szabályozások megalkotása során az említett országok a régi tagállamok szabályozásából merítettek ihletet. Olyan szabályozásokból, amelyek nagy részét az Európai Unió Bizottsága vagy az Európai Unió Bírósága a

György Marinkás: Certain Aspects of the Agricultural Land Related Case Law of the European Court of Human Rights - Az Emberi Jogok Európai Bíróságának mezőgazdasági földekkel kapcsolatos ítélkezési gyakorlatának aspektusai. Journal of Agricultural and Environmental Law ISSN 1788-6171, 2018 Vol. XIII No. 24 pp. 99-134 doi: 10.21029/JAEL.2018.24.99

* dr. jur., PhD, adjunktus, Miskolci Egyetem, Állam- és Jogtudományi Kar, Európajogi és Nemzetközi Magánjogi Tanszék, e-mail: joggyuri@uni-miskolc.hu

** A tanulmány az Igazságügyi Minisztérium jogásそképzés szinvonalának emelését célzó programjai keretében valósult meg.

${ }^{1}$ Emberi Jogok Európai Egyezménye, Róma, 1950. november 4.

2 Az EJEBiz 1998-ban szűnt meg az EJEE 11. jegyzőkönyve értelmében.

3 ENSZ KGY A/HRC/13/33/Add.2 jelentés, para. 33; EGSZB: Földszerzés - figyelmętetés Európának és közelgö veszély a családi gazdaságokera (NAT/632, Földszerzés/családi gazdaságok, Brüsszel, 2015. január 21.); Európai Bizottság Mezőgazdasági és Vidékfejlesztési Foóigazgatóság: A földrablás mértéke az EU-ban (Extent of Farmland Grabbing in the EU), 2015; EP Mezőgazdasági és Vidékfejlesztési Bizottság: A termớfoildek koncentrációjának jelenlegi állapota az. Unióban: a merốgazdasági termelök földhöz jutásának megkönnyitése című kérdésrőll (2016/2141(INI), 2017.03.30, dokumentum szám: A8-0119/2017); Az Európai Agrárjogi Biæoottság (Comité Européen de Droit Rural, a továbbiakban: CEDR) 2015-ös Potsdami konferenciájának záró dokumentuma. Lásd: Szilágyi János Ede: Következtetések, Journal of Agricultural and Environmental Law (JAEL), 2015/19, 96-102; Európai Bizottság: Bizottsági értelmező közlemény a termőföld megvásárlása és az uniós jog kapcsolatáról, Az Európai Unió Hivatalos Lapja, (2017/C 350/05). 
korábbi vizsgálatai során - amennyiben egyáltalán vizsgálatot indított - , rendben lévőnek talált. ${ }^{4}$

Jelen írás nem foglalkozik tisztán uniós, ${ }^{5}$ és alkotmányjogi kérdésekkel ${ }^{6}$ e témakört már több más szerző részletesen körbe járta -, helyette az EJEB joggyakorlatának egy bizonyos részét tanulmányozza. A szerzô négy ügytípust elemzett a mezőgazdasági földekhez kapcsolódóan: (i) azokat a kárpótlási ügyeket, ahol ütközött a korábbi tulajdonosok vagy azok örökösei és a jóhiszeműen tulajdont szerző felek érdeke; (ii) a földrendezésből eredő jogvitákat; (iii) a környezetvédelmi megfontolásból véghezvitt tulajdon elvonást, illetve a használat jogának korlátozását, és végül a (iv) mezőgazdasági üzemek elaprózódását megakadályozni hivatott öröklési szabályokat. Ezen ügyek megmutatják, hogy az államnak milyen garanciális feltételeknek kell eleget tennie, amikor a mezőgazdasági földeket érintő törvénykezésbe kezd, illetve amikor e törvényeket végrehajtja.

Az EJEB gyakorlatának e része a szerző véleménye szerint hasznos tanulságokkal szolgálhat a termőföldet érintő uniós jogi kérdések terén is, különös tekintettel a folyamatban lévő speciális kötelezettségszegési eljárásra. Az említett vizsgálat keretében az Európai Bizottság a mezó- és erdögazdasági földek forgalmáról szóló 2013. évi CXXII. törvény (a továbbiakban: földforgalmi törvény) egyes rendelkezéseinek végrehajtásáról rendelkező a mezó- és erdógazdasági földek forgalmáról szóló 2013. évi CXXII. törvénnyel összefüggó egyes rendelkeąésekeról és átmeneti szabályokról szóló 2013. évi CCXII. törvény (a továbbiakban: Fétv.) 108. paragrafusát vizsgálja. Az említett paragrafus értelmében a termőföldre nem közeli hozzátartozók által kötött haszonélvezeti jogok a törvény erejénél fogva 2014. május 1-én megszűntek.

A jelen írás két szempontból közelíti meg a kérdést: egyrészröl a tisztességes eljárás és a hatékony jogorvoslathoz való jog szempontjából - EJEE 6 és 13 cikkek -, másrészrôl az EJEE első kiegészítő jegyzőkönyv ${ }^{7}$ (a továbbiakban: első kiegészítő jegyzőkönyv) első cikke által rögzített tulajdonjog sérelme szempontjából. Az első kapcsán a szerző arra keresi a választ, hogy az EJEB gyakorlata alapján mennyire tartható az egyes ügyek bírói vizsgálatát kizáró törvényi vélelem, miszerint minden

4 Papik Orsolya: A Tagállamok birtokpolitikai mozgásterével kapcsolatos trendek, aktuális kérdések - Pódiumbeszélgetés, JAEL, 2017/22, 146-159, doi: 10.21029/JAEL.2017.22.132

5 Andréka Tamás - Olajos István: A földforgalmi jogalkotás és jogalkalmazás végrehajtása kapcsán felmerült jogi problémák elemzése, Magyar Jog, 2017/7-8, 410-424; Raisz Anikó: Topical Issues of the Hungarian land-transfer law Purchasing and Renting Agricultural Land: Legal framework and practical problems, CEDR-Journal of Rural Law, 2017/1, 68-74; Szilágyi János Ede: A magyar földforgalmi szabályozás új rezsimje és a határon átnyúló tulajdonszerzések, Miskolci Jogi Szemle, 2017/1 Különszám, 107-124; Szilágyi János Ede: Az új tagállamok csatlakozási szerződései és a termőföldek tulajdonjogára vonatkozó nemzeti szabályozások, különösen a magyar jogi szabályozás, JAEL, 2010/9, 48.

${ }^{6}$ Olajos István: Az Alkotmánybíróság döntése a helyi földbizottságok szerepérôl, döntéseiről, és az állásfoglalásuk indokainak megalapozottságáról, Jogesetek Magyarázata, 6/3, 17-32; Téglási András: Termőföldvédelem az Alkotmánybíróság gyakorlatában és az Alaptörvényben, in: Korom Ágoston (szerk.): Az új magyar földforgalmi szabályozás az uniós jogban, Budapest, Nemzeti Közszolgálati Egyetem, 2013, 93-107.

${ }^{7}$ EJEE első kiegészítő jegyzőkönyv, Párizs, 1952. március 20. 
egyes, termőföldre alapított haszonélvezeti jog a korábban hatályos törvényi szabályok megkerülését célozta volna, és amelynek orvoslására a törvényhozó az ex lege megszüntetést találta a legmegfelelőbb megoldásnak. Az EJEB joggyakorlatát ismerve, abban már a kutatás elkezdésekor biztos volt a szerző, hogy a bírói felülvizsgálat kizárását - amennyiben eljárás indulna előtte - az EJEB minden bizonnyal ellentétesnek találná tisztességes eljárás és a hatékony jogorvoslathoz való jog követelményével. Ahogyan a rendelkezést a közösségi jog ${ }^{8}$ szempontjából vizsgáló Európai Unió Bíróságának a főtanácsnoka is aránytalannak, összességében az uniós joggal ellentétesnek találta. ${ }^{9}$ - Az EJEB joggyakorlata alapján, bár az államoknak széles mozgástere van a hazai igazságszolgáltatási rendszer kialakítása terén, ideértve azt is, hogy mely esetekben kell a bíróságoknak nyilvános meghallgatást tartaniuk és mely esetekben nem, az egyes ügyek bírói felülvizsgálata nem tagadható meg az érintett felektől. A haszonélvezeti jog törvényi elvonása, az egyes ügyek egyenként történő bírósági felülvizsgálata nélkül tehát - minden valószínűség szerint -, aggályosnak tekinthetô.

Míg a szerző a tisztességes eljáráshoz való jog kapcsán szilárd alapokra tudta helyezni a vizsgálódást, addig a vizsgálat másik fókusæpontja, a tulajdonjog sérelme kapcsán kénytelen volt a polgárjogi dogmatikában ${ }^{10}$ kevésbé elfogadott álláspontra helyezkedni. A szerző azzal is tisztában van, hogy az írás e része könnyen kritikai észrevételek tárgyává válhat. Tökéletes analógiát jelen írás szerzője nem talált, legjobb tudomása szerint nem létezik precedens ehhez hasonló intézkedésre más államokban, amelyek részesei az EJEE-nek. Ellentmond továbbá a haszonélvezeti jog tulajdonjellegének az AB 25/2015 (VII.21.) sz. határozatában rögzített álláspontja, amelynek értelmében a kérdéses törvényi rendelkezést nem a tulajdonjog elvonásának szabályai szerint kell megítélni: egy kötelmi jogviszony szűnik meg, amelyre a tulajdonhoz való joggal ellentétben, kevésbé szigorú szabályok vonatkoznak. ${ }^{11} \mathrm{Az}$ AB mulasztást csak annak kapcsán állapított meg, hogy „[az OGY] nem alkotta meg a kivételes, a szerződő felek közötti elszámolás során nem érvényesíthető, de érvényes szerződésekkel összefüggő vagyoni hátrányok kiegyenlítését lehetővé tevő szabályokat."12 Ebből kifolyólag az egykori haszonélvezôk és a tulajdonosok közötti elszámolás során, a felek egyes költségei és kiadásai nem kerülnek megtérítésre.

Ellentétben ugyanakkor az említett $\mathrm{AB}$ határozatba foglalt fó értelmezési iránnyal, nem szabad megfeledkezni arról, hogy amint azt Andréka Tamás is írja: a haszonélvezet személyes szolgalom, amelynek jogosultját több, a tulajdonjogból eredó

\footnotetext{
${ }^{8}$ A szerző a főtanácsnoki indítvány említésével nem kívánja összemosni a közösségi jogot, illetve az EuB joggyakorlatát az EJEB joggyakorlatával, pusztán arra kíván utalni, hogy a vizsgált rendelkezések több fronton támadhatók.

${ }^{9}$ Lásd: EuB, C-52/16 és C-113/16 sz. SEGRO és Horváth egyesitett ügyek, Henrik Sangmandsgaard Øe főtanácsnoki indítványa, 2017. május 31, 92-97.

${ }^{10}$ Külön köszönet Les₹łoven Lászlónak, amiért a témában tartott konzultációkkal segítette a kutatásomat.

11 25/2015 (VII.21.) sz. AB határozat, 53-66.

12 25/2015 (VII.21.) sz. AB határozat, 67.
} 
résæjogosituány is megilleti. ${ }^{13}$ A legmesszebbre talán Sulyok Tamás alkotmánybíró ment, aki az 5/2016. (III.1.) AB határozathoz füzött párhuzamos indokolásában egyenesen azt írja, hogy „egy ingatlanra vonatkozó haszonélvezeti jog lényeges, dologi jogi jószágnak. tekinthetó". ${ }^{14}$

A dolgozat szerzője szerint tehát, amennyiben a haszonélvezeti jog kvázi tulajdonjogként kezelhető, úgy vizsgálandó, hogy annak elvonása törvényen alapszik-e, törvényes célra irányul-e, illetve arányosnak tekinthető-e? Az első kérdésre, miszerint törvény alapján történik-e, a válasz nyilvánvalóan igen, a másik kettőre azonban nem ilyen egyértelmű a válasz. Törvényes célnak minősül az állam korábbi tévedésének a korrigálása, amely jelen esetben jelentheti azt is, hogy a magyar állam olyan szabályozást alkotott a rendszerváltást követően, amely kijátszható volt, sőt egyes szerzők szerint egyenesen erre sarkalta a magánszemélyeket. ${ }^{15}$ Az arányosság kapcsán vizsgálandó, hogy a kapott kártérítés, amennyiben egyáltalán kapnak az érintett felek, arányos-e az elvont tulajdonnal? Amint az fentebb említésre került, az elszámolás nem minden aspektusára terjed ki a törvény hatálya, az államtól pedig azok a haszonélvezők sem várhatnak kárpótlást, akik adott esetben jóhiszeműen kötöttek haszonélvezeti jogot.

A kérdések tehát adottak, a válaszokat pedig az alább részletezett ügyek adják meg.

\section{Az EJEB és az EJEBiz joggyakorlata}

\subsection{A kártérítési ügyek}

A kártérítési ügyekkel Raisz. Anikó foglalkozott behatóan, értékes megállapításokat téve az EJEB joggyakorlatában fellelhető visszásságok kapcsán. ${ }^{16}$ A kártérítési ügyek közül jelen írás azokkal foglalkozik, amelyekben a korábban kisajátított ingatlanokon harmadik, jóhiszeműen szerző felek szereztek tulajdonjogot az államtól vagy magánszemélytől, és akikkel szemben a korábbi tulajdonosok vagy azok örökösei kárpótlási igénnyel léptek fel, jellemzően sikerrel. Tekintve, hogy az ügyek tényállása jellemzően hasonlít, azok részletes ismertetésétől a szerző eltekint.

A Pincová és Pinc ügyben ${ }^{17}$ a panaszos felek által korábban vásárolt ház visszaszolgáltatása iránt, az elkobzást elszenvedő tulajdonos örököse 1992-ben nyújtotta be igényét, amelyet sikerrel érvényesített a nemzeti bíróság előtt. ${ }^{18} \mathrm{~A}$ panaszos felek arra hivatkozva kérték a tulajdonhoz való joguk sérelmének megállapítását, hogy a ház

\footnotetext{
13 Andréka - Olajos 2017, 417.

14 5/2016. (III.1.) AB határozat, Sulyok Tamás párbuzamos indokolása, 63.

15 Andréka - Olajos 2017, 417.

16 Raisz Anikó: A Beneš-dekrétumok által érintett tulajdoni kérdések az Emberi Jogok Európai Bírósága előtt, in: Horváth Attila - Korom Ágoston (szerk.): Beneš-dekrétumok az Európai Parlamentben, Budapest, Nemzeti Közszolgálati Egyetem, 2014, 64-72; Raisz Anikó: Földtulajdoni és földhasználati kérdések az emberi jogi bíróságok gyakorlatában, in: Csák Csilla (szerk.): Az európai földszabályozás aktuális kibivásai, Miskolc, Novotni Alapítvány, 2010, 241-253.

17 EJEB, Pincová és Pinc k. Csehország, 2002. November 5. (36548/97).

18 Pincová és Pinc k. Csehország 2002, 9-32.
} 
megvásárlásánál jóhiszeműen léptek szerződésre, és a nemzeti bíróság ítélete nyomán nem részesültek az elszenvedett kárral arányos kártérítésben. ${ }^{19} \mathrm{Az}$ EJEB megállapította, hogy jelen esetben a tulajdontól való megfosztás esete áll fenn. A korábbi ítélkezési gyakorlatát idézve rögzítette, hogy a tulajdontól való megfosztásnak törvényen kell alapulnia, törvényes célra - közérdek - kell irányulnia, valamint arányosnak kell lennie, azaz igazságos egyensúlyt kell teremtenie a közérdek és az egyéni szabadságjogok között. Jelen ügyben a panaszos felek sem vitatták, hogy az állam intézkedése törvényen alapult. ${ }^{20}$ A törvényes cél kapcsán a Bíróság emlékeztetett a James ügyben ${ }^{21}$ tett megállapításaira, miszerint „elsösorban a nemzeti kormányok (vagy a törvényhozás) vannak abban a helyzetben, hogy ismerjék a társadalmuk igényeit és ennek megfelelo" intézkedéseket hozzanak [...] feltéve, hogy az. nem nélkë̈löz. minden ésszerü alapot. ${ }^{22} \mathrm{E}$ megállapításból következik az is, hogy a közérdek szükségszerűen tág fogalom. ${ }^{23}$ A Bíróság megvizsgálta, hogy a törvény igazságos egyensúlyt teremtett-e a közérdek és az alapvető egyéni jogok között, e tekintetben vizsgálta a kompenzáció mértékét, amelynek alapvetően a piaci árhoz közelítőnek kell lennie, ugyanakkor a teljes kompenzáció nem várható el minden esetben. Tekintve, hogy a szóban forgó ügyben a panaszos felek által kapott kártérítés a ház jelenlegi piaci értékének az egyötöde, az államnak nem sikerült megteremtenie a fent említett egyensúlyt, következésképpen sérült a tulajdonhoz való jog. ${ }^{24}$

A Velikovi ${ }^{25}$ név alatt jegyzett egyesített ügyek azért érdemelnek kiemelést, mert a panaszos felek között egyaránt találni tulajdonosokat és hosszú távú bérleti joggal rendelkező feleket, amely némileg hasonlatossá teszi a helyzetüket a magyar szabályozás által érintett haszonélvezőkkel. Továbbá a Fétv. szabályaihoz hasonlóan - egy rövid időszakot kivéve - a bolgár szabályozás sem rendelkezett az érintett felek megfelelő kártérítésérôl. ${ }^{26} \mathrm{Az}$ EJEB részletezte a bolgár bíróságok joggyakorlatát, amelyek a legtöbb esetben formai hibára ${ }^{27}$ hivatkozva érvénytelenítették az előző rendszerben kötött szerződéseket és ítéltek a kárpótlást kérő személyek javára. ${ }^{28}$ Az egyesített ügyek közül azokban, ahol formai hiba miatt történt az érvénytelenítés és a panaszos felek részesültek valamennyi kártérítésben - ahogyan a névadó Velikovi-ügyben is, - az EJEB nem állapította meg a tulajdonjog sérelmét. ${ }^{29} \mathrm{Az}$ EJEB az ügy körülményeinek értékelése során utalt ${ }^{30}$ a Jahn és mások kontra Németország ügyben tett megállapításaira, miszerint „a volt keleti bloke államai különleges helyzetben voltak a radikális társadalmi-gazdasági átalakulás idején.’’1

\footnotetext{
${ }^{19}$ Pincová és Pinc k. Csehország 2002, 42.

${ }^{20}$ Pincová és Pinc k. Csehország 2002, 47-51.

${ }^{21}$ EJEB, James és mások k. Egyesült Királyság, 1986. február 21., (8793/79).

${ }^{22}$ James és mások k. Egyesült Királyság 1986, 46.

23 James és mások k. Egyesült Királyság 1986, 46.

24 Pincová és Pinc k. Csehország 2002, 52-64.

${ }_{25}$ EJEB, Velikovi és mások. k. Bulgária, 2007. március 15, (43278/98).

26 Velikovi és mások k. Bulgária 2007, 128-141.

27 Példának okáért delegálás a törvényi előírásokkal szemben.

${ }^{28}$ Velikovi és mások k. Bulgária 2007, 110-113; 117-120; 121-125.

${ }^{29}$ Velikovi és mások k. Bulgária 2007, 194-200.

${ }^{30}$ Velikovi és mások k. Bulgária 2007, 169.

${ }^{31}$ EJEB, Jahn és mások. k. Németország, 2005. június 30. (46720/99, 72203/01 and 72552/01), 99.
} 
A Pyrantiená k. Litvánia ügyben ${ }^{32}$ - a korábban ismertetett ügyekkel javarészt hasonló tényállás mellett - a Bíróság arra a következtetésre jutott, hogy az egyes ügyek külön-külön történó birói felïlvizsgálatát kizáró szabályozás ellentétes az. EJEE rendelkezéseivel. A Bíróság a korábbi joggyakorlatát - Pincová ügy - idézve emlékeztetett, hogy a korábbi sérelmek orvoslása nem vezethet új sérelmek keletkezéséhez.

E végett a törvényhozásnak olyan szabályozást kell alkotnia, amely lehetővé teszi a bíróságok számára, hogy minden egyes ügyet egyenként, azok minden körülményét - ideértve a tulajdonelvonás körülményeit, a kapott kárpótlást és a panaszos fél szociális helyzetét ${ }^{33}$ - figyelembe véve rendezzék. A szabályozás nem eredményezheti azt, hogy az egyénnek aránytalanul nagy terhet kelljen viselnie. - Olyan terhet, amely teljes egészében vagy elsősorban az állam magatartásának eredményeként keletkezett. ${ }^{34}$

Különösen érdekes kérdést vetnek fel azok az ügyek, ahol az állam - kártérítés címén - olyan magánszemélyeket fosztott meg föld vagy lakástulajdonuktól, akik nem közvetlenül a kisajátításban részt vevő államtól vagy állami vállalattól szerezték meg az érintett ingatlant, hanem egy másik magánszemélytől, aki korábban maga is az államtól szerezte meg az eredeti tulajdonostól - az államosítás során - elvett ingatlant. Bulgáriában az ilyen esetek különösen gyakoriak voltak.

A Tomov és Nikolova k. Bulgária ügyben ${ }^{35}$ az egykori tulajdonos örökösei 1991 ben kérvényt nyújtottak be a helyi földbizottsághoz a föld visszaszolgáltatására, amely 1996. április 4-én eleget tett a kérésnek. Az örökösök ezt követően elidegenítették a földet K. Úr részére, aki 2003-ban jogi lépéseket tett a földet egykoron, jóhiszeműen szerző panaszos felekkel szemben, hogy ténylegesen is a birtokába kerüljön a kérdéses földbirtok. A legfelsőbb bíróság itélete értelmében a kártéritést kéró" személyek vagy azok örököseinek igényei megelörik a jóhiszemüen tulajdont szerző felek igényeit. ${ }^{36}$

A panaszos felek kérték a tulajdonhoz való jog és az EJEE 13. cikke által garantált hatékony jogorvoslathoz való jog sérelmének megállapítását. Utóbbi vizsgálatát a Bíróság nem tartotta szükségesnek. ${ }^{37}$

Az állam érvelésével ellentétben, az EJEB rámutatott, hogy az állam, még ha a szerződés megkötésében nem is vett részt; felelős azért, hogy olyan jogszabályi környezetet hozott létre, amely elsőbbséget biztosított a kártérítést kérőknek a jogszerűen és jóhiszeműen szerző tulajdonosokkal szemben, az utóbbiak kárpótlásáról szóló rendelkezés nélkül is. A Bíróság többek között emiatt, a tényállásban fellelhető eltérést nem látta kellő indoknak arra, hogy mellőzze a Velikovi ügyben rögzített elveket. ${ }^{38}$ Ahogyan a Velikovi ügyben, az EJEB itt is utalt rá, hogy a volt keleti blokk

\footnotetext{
32 EJEB, Pyrantiená k. Litvánia, 2013. november 12. (45092/07).

33 Az EJEB hivatkozik a Mobylová k. Cseb Köztársaság, 2005. szeptember 6 (75115/01) ügyre.

34 Pyrantiená k. Litvánia 2013, 50-51.

35 EJEB, Tomov és Nikolova k. Bulgária, 2016. július 21. (50506/09).

36 Tomov és Nikolova k. Bulgária 2016, 6-12.

37 Tomov és Nikolova k. Bulgária 2016, 20, 21.

38 Tomov és Nikolova k. Bulgária 2016, 35, 41.
} 
államaival kapcsolatban enyhébb megítélést alkalmazott az átmeneti években. ${ }^{39} \mathrm{Ez}$ a kegyelmi időszak azonban csak a rendszerváltás éveire és az azt követő egy-két évre vonatkozott, a kérdéses bolgár szabályozás azonban 1997-ben - évekkel a rendszerváltás követően - került törvénybe foglalásra, amely miatt a Bíróság arra a következtetésre jutott, hogy az adott törvényi rendelkezés nem tekinthető sem törvényes célra irányulónak, sem olyannak, mint amely megfelel a jogbiztonság követelményének. Tekintettel a kártérítés hiányára és arra, hogy sérült a jogbiztonság elve, az állami törvénykezést aránytalannak minősítette és megállapította a tulajdonjog sérelmét. 40

Krasteva és mások k. Bulgária ${ }^{41}$ ügy tényállása ${ }^{42}$ szinte egy az egyben megegyezik a fentebb említett Tomov és Nikolova ügy tényállásával. A hasonlóság az EJEB számára is szembetűnő volt, erre tekintettel a Bíróság adatokat kért az államtól arra nézve, hogy hány hasonló ügyet tárgyalnak a tagállami bíróságok egy-egy évben. Az állam válasza szerint éves átlagban 35-50 ügy került az elsőfokú bíróság elé, 2010 és 2014 között. ${ }^{43}$ A panaszos felek a beadványukban a tulajdonhoz való jog, a tisztességes tárgyaláshoz való jog és ahhoz kapcsolódóan a diszkrimináció tilalma sérelmének a megállapítását kérték. Utóbbi kettő vizsgálatát ugyanakkor Bíróság nem tartotta szükségesnek, egyedül a tulajdonjog sérelmét állapította meg. ${ }^{44}$

\subsection{Földrendezés}

Az EJEB joggyakorlatában a földrendezéssel kapcsolatos ügyek jellemzően Ausztria vonatkozásában lelhetők fel. A földrendezés lényege, hogy a széttöredezett birtokokat a gazdák egymás közötti megállapodásukkal és a hatóság jóváhagyásával vagy a hatóság által levezetett eljárás révén újból összefüggővé teszik oly módon, hogy egymás között elcserélik a parcellákat. Az eljárás célja, hogy gazdaságosan megművelhetô parcellákat hozzanak létre. Ezen eljárások természetüknél fogva komplexek és időigényesek, tekintve, hogy az érintett földek eltérő méretűek és minőségűek. ${ }^{45}$ Ebből is következően szinte kivétel nélkül akad egy vagy több olyan gazda, aki vagy eleve nem szeretett volna részt venni a földcserében, de kötelezték a részvételre, vagy aki ugyan önként vett részt az eljárásban, a végeredmény kapcsán azonban úgy érezte, hogy rosszul járt a cserével. A földrendezéssel kapcsolatos panaszokban a panaszos felek jellemzően a tulajdonjog és a tisztességes eljáráshoz való jog sérelmének megállapítását kérték. Előbbit jellemzően arra tekintettel, hogy elvonták tőlük a tulajdonukat, és nem részesültek - a szerintük - megfelelő mértékú

\footnotetext{
39 Amely azt jelentette, hogy a rendszerváltással összefüggő társadalmi és gazdasági átrendeződéssel kapcsolatos ügyekben, szélesebb mérlegelési jogkört engedett meg az állami törvényhozóknak a közérdeket illetően.

40 Tomov és Nikolova k. Bulgária 2016, 43, 44, 48, 51, 54-55.

41 EJEB, Krasteva és mások k. Bulgária, 2017. június 1. (5334/11).

42 Krasteva és mások k. Bulgária 2017, 5-10.

43 Krasteva és mások k. Bulgária 2017, 20-23.

44 Krasteva és mások k. Bulgária 2017, 17-18, 22-30.

45 Egyáltalán nem mindegy például, hogy mennyire belvizes vagy benapozott az adott terület.
} 
kompenzációban; míg utóbbit az ügyek hosszan elhúzódó voltára vagy a szóbeli meghallgatásra irányuló kérelmük szerintük indokolatlan elutasítására hivatkozva.

A földrendezéssel kapcsolatos ügyekben a tulajdonjog sérelmének vizsgálatát külön érdekessé teszi, hogy az osztrák törvények értelmében a földrendezésrôl szóló döntés alapján végbemenő kötelező átruházás révén megszűnik a tulajdonosok tulajdonjoga, ${ }^{46}$ következésképpen a Bíróság joggyakorlata ${ }^{47}$ értelmében nem létezik az egyezmény vagy valamely kiegészítő jegyzőkönyve alapján védelemben részesítendő jog. Továbbá, mivel az osztrák törvények értelmében az átruházást követően bekövetkező értékváltozás nem vehető figyelembe, jogos igény sem keletkezik, ${ }^{48}$ amely adott esetben tulajdonként lenne értékelhető. ${ }^{49}$ Ily módon akadt olyan ügy, ahol az EJEB a tényállást figyelembe véve, elutasította a tulajdonjog sérelmének vizsgálatát. ${ }^{50}$

Az Erkner és Hofauer k. Ausztria ügyben ${ }^{51}$ a panaszos felek, az idézés ellenére nem jelentek meg az első meghallgatáson, ahol távollétükben született döntés. Még ugyanazon évben egy másik meghallgatáson az ügyvédjük jelenlétében kérték, hogy a terv földjüket érintő részét tárgyalják újra, ugyanis a számukra felajánlott föld rosszabb minőségū, árnyékosabb és messze van a lakóhelyüktől. E kérésnek a hatóságok nem tettek eleget. ${ }^{52}$

A panaszos felek kérték az EJEE 6, 8, 14 cikkének és az első kiegészítő jegyzőkönyv első cikke megsértésének megállapítását, amelyből az EJEBiz az EJEE 6. cikk és az első kiegészítő jegyzőkönyv első cikke megsértésének vizsgálatát javasolta a Bíróságnak.

A Bíróság először a 6. cikk sérelmének kérdésével foglalkozott érdemben: utalva a korábbi ítélkezési gyakorlatára megállapította, hogy az ésszerű idő kérdésének elbírálása során a kiinduló időpont rendszerint a hazai bíróságok előtti eljárások kezdete $^{53}$ - ahogyan a jelen ügyben is -, azonban bizonyos esetekben annál korábbi időpont is lehet. ${ }^{44}$ Szintén a korábbi joggyakorlatára ${ }^{55}$ hivatkozva emlékeztetett rá, hogy az eljárás ésszerű idôn túli elhúzódása esetén a Bíróság az alábbi szempontokat vizsgálja: (i) az ügy komplexitása; (ii) a panaszos fél és (iii) a hatóságok magatartása. Jelen esetben az ügy kétségkívül komplex volt, tekintve, hogy a végére már 38

\footnotetext{
${ }^{46}$ Lásd: EJEB, Prischl k. Ausztria, 2007. április 27. (2881/04), 35-37.

${ }^{47}$ EJEB, Marckx k. Belgium, 1979, június 13. (6833/74), 50.

${ }^{48}$ EJEB, Kolb és mások. k. Ausztria, 2002. február 21. (35021/97), (45774/99).

49 EJEBiz, A, B, C, D, E, F, G, H és I k. Német Sqövetségi Köztársaság, 1976. július 16. 1976 (5573/72 és 5670/72), DR 7, 8; EJEBiz, Consorts D. k. Belgium, 1988. december 18. (11966/86).

${ }^{50}$ Prischl k. Ausztria 2007.

${ }^{51}$ EJEB, Erkner és Hofauer k. Ausztria, 1987. március 24. (9616/81), érdemi ítélet.

52 Erkner és Hofauer k. Ausztria 1987, 8-36.

${ }^{53}$ EJEB, Kern k. Ausz̨tria, 2005. február 24 (14206/02), 51; Kolb, 49; EJEB, Wiesinger k. Ausżtria, 1991. október 30. 52; EJEB, Deumeland k. Németország, 1986. május 29, (9384/81), 77.

${ }^{54}$ EJEB, Golder k. Egyesült Királyság, 1975. február 21, (4451/70), 32.

55 Többek között: EJEB, Frydlender k. Franciaország, 2000. június 27. (30979/96), 43; Wiesinger, Op. cit. 54; EJEB, Zimmermann és Steiner k. Svájc, 1983. július 13, (8737/79), 66; EJEB, Buchbolz k. Németország, 1981. május 6, (7759/77), 49.
} 
földtulajdonost érintett, mindent figyelembe véve azonban az EJEB szerint a 16,5 évig húzódó eljárás nem tekinthető ésszerű időn belülinek. ${ }^{56}$

A tulajdonhoz való jog kapcsán a Bíróság arra jutott, hogy jelen esetben a tulajdonjog békés élvezetének a joga sérült (első kiegészítő jegyzőkönyv, első bekezdés, első mondat), mivel se de jure, se de facto kisajátítás nem történt. ${ }^{57}$ Ami a közérdek és az egyéni szabadságjogok közti egyensúlyt illeti, az eljárás, mint fentebb megállapításra került, 16,5 évig húzódott. Habár a kormány szerint az eljárás elhúzódása nem vizsgálható a tulajdonjog sérelme alapján, a Bíróság emlékeztetett rá, hogy az ítélkezési gyakorlata ${ }^{58}$ alapján egy-egy ténybeli elem az egyezmény és kiegészítő jegyzőkönyveinek több rendelkezését is sértheti, azaz felcserélhetők egymással. A Bíróság az eset összes körülményének tanulmányozása során egyebekben arra a következtetésre jutott, hogy a közigazgatási szerveknek nem sikerült egyensúlyt teremteniük a közérdek és az egyéni szabadságjogok között. ${ }^{59}$

Az Ernst és Anna Lughofer k. Ausztria ügyben ${ }^{60}$ az osztrák hatóságok 1973-ban kezdeményeztek földrendezést, amelynek során nyilvános meghallgatást is tartottak. Az eljárás eredményeként a hatóságok kibocsátottak egy földrendezési tervet, amely ellen a panaszos felek fellebbeztek arra hivatkozva, hogy nem kaptak kellő mértékủ kártérítést. ${ }^{61}$ Kérelmükben a panaszos felek arra hivatkozva kérték a 6 . cikk sérelmének megállapítását, hogy a közigazgatási bíróság elutasította, hogy nyilvános meghallgatást tartson. Az EJEBiz egyetértett a panaszos felekkel, és maga a kormány sem vitatta a jogsértés tényét. E tényre, valamint arra való tekintettel, hogy Bíróság korábbi joggyakorlata is ebbe az irányba mutatott a hasonló ügyekben, megállapította a jogsértést. ${ }^{62}$

A Walder k. Ausztria ügyben ${ }^{63}$ a panaszos fél szintén az ügy ésszerűtlen ideig húzódó volta miatt kérte a tisztességes eljáráshoz való jog sérelmének megállapítását. A Bíróság ez esetben is rögzítette a földrendezési ügyek komplex voltát, valamint az eljárás elhúzódása kapcsán vizsgálandó szempontokat, valamint megállapította a jogsértést. ${ }^{64}$

A Prischl k. Ausztria ügyben a panaszos fél arra hivatkozva nyújtott be keresetet, hogy földjei értékesebbek, mint annak idején becsülték, és a földet örökül hagyó néhai férjét sem kárpótolták teljes mértékben. Erre hivatkozva kérte a tulajdonjog sérelmének megállapítását. ${ }^{65}$ A panaszos fél ugyanakkor elsősorban a tisztességes eljáráshoz való jog sérelmének a megállapítását kérte arra hivatkozva, hogy az eljárás elhúzódása sértette az

\footnotetext{
56 Erkner és Hofauer 1987, 63-70.

57 Erkner és Hofauer 1987, 71-74.

58 EJEB, Airey k. Írország, 1979. október 9, (6289/73), 31-33.

${ }^{59}$ Erkner és Hofauer 1987, 76, 79, 80.

60 EJEB, Ernst és Anna Lughofer k. Ausztria, 1999. november 30. (22811/93).

61 Ernst és Anna Lughofer k. Ausztria, 1999, 6-9.

62 Ernst és Anna Lughofer k. Ausztria, 1999, 13-14, 16-18.

${ }^{63}$ EJEB, Walder k. Ausżtria, 2001. január 30., (33915/96).

64 Walder k. Ausztria 2001, 26-33.

65 Prischl k. Ausztria 2007, 4-16, 34.
} 
ésszerű idő követelményét, igazságtalan volt és a bírói fórumok nem biztosítottak nyilvános meghallgatást a panaszos fél számára. ${ }^{66}$

A hatodik cikk sérelme kapcsán, az EJEB csak az eljárás hosszát vizsgálta, a másik két panaszt befogadhatatlannak nyilvánította. A Bíróság rámutatott, hogy az ítélkezési gyakorlata alapján a földreform bizottságok bíróságnak minösülnek, így az általuk tartott nyilvános meghallgatás bíróság előtti meghallgatásnak minősül. ${ }^{67}$ Következésképpen a panasszal érintett jogsértés sem következett be. A panaszos fél azon állítására, miszerint az eljárás nem volt fair, a Bíróság megjegyezte, hogy az ítélkezési gyakorlata ${ }^{68}$ alapján a nemzeti hatóságok és bíróságok eljárása csak akkor vizsgálható a Bíróság által, ha azok valamely, az Egyezményben garantált jogba ütköznek. Az Egyezmény azonban nem tartalmaz semmilyen kitételt arra vonatkozóan, hogy a nemzeti bíróságoknak milyen bizonyítékokat kell befogadniuk vagy hogyan kell azokat értékelniük. Az eljárás hosszát illetően a Bíróság a többi hasonló ügyben foglalt szempontokat rögzítette. Mindent figyelembe véve, megállapította a 6. cikk (1) bekezdés sérelmét. ${ }^{69}$

A tulajdonjog sérelme kapcsán az EJEB utalva arra, hogy a panaszos félnek tulajdonképpen nem volt meglévő tulajdonjoga, ${ }^{70}$ amely védelemben részesülhetne, a Bíróság a beadvány e részét nem vizsgálta. ${ }^{71}$

Az Ortner k. Austria ügyben ${ }^{72}$ a panaszos fél a tisztességes eljáráshoz való jog, valamint a tulajdonhoz való jog sérelmének megállapítását kérte. Előbbit az ügy ésszerűtlen elhúzódása miatt kérte megállapítani. Hasonló ügyekben ${ }^{73}$ a Bíróság gyakran állapította meg az eljárások ésszerű időt meghaladó voltát. Jelen ügyben a tényállás meglehetôsen komplex volt, ${ }^{74}$ az eset összes körülményét figyelembe véve az eljárás ésszerūtlenül sokáig húzódott, így a Bíróság megállapította a hatodik cikk sérelmét. ${ }^{75}$

A Bíróság a tulajdonhoz való jog sérelmét nem vizsgálta, egyrész̨t, mert a panaszos fél nem tudta bizonyítani, hogy a tulajdonjoga elvesztése kapcsán aránytalanul nagy terhet kellett volna elszenvednie; másrés žt az eljárás hossza pedig önmagában nem elegendő annak megállapítására, hogy sérült volna a tulajdonhoz való jog. ${ }^{76}$

\subsection{Környezetvédelem}

A Matos e Silva 77 ügyben a legfontosabb kérdés az volt, hogy a Matos e Silva egy spanyol cég - rendelkezett-e az egyezmény első kiegészítő jegyzőkönyve szerinti

\footnotetext{
${ }^{66}$ Prischl k. Ausztria 2007, 18.

${ }^{67}$ EJEB, Stallinger és Kuso k. Ausztria, 1997. április 23. (14696/89 14697/89), 37.

${ }^{68}$ EJEB, García Ruiz. k. Spanyolország, 1999. január 21. (30544/96), 28.

${ }^{69}$ García Ruiz k. Spanyolország 1999, 21, 24, 29-33.

${ }^{70}$ Ahogyan az a jelen alfejezet bevezetőjében is kifejtésre került.

${ }^{71}$ Prischl k. Ausztria 2007, 35-37.

72 EJEB, Ortner k. Austria, 2007. május 31., (2884/04).

${ }^{73}$ Lásd a Kolb és mások ügyet!

${ }^{74}$ Mint a Wiesinger ügyben, 55.

75 Ortner k. Austria 2007, 21-23, 30-34.

${ }^{76}$ Ortner k. Austria 2007, 36-37.

${ }_{77}$ EJEB, Matos e Silva Lda. és mások k. Portugália, 1996. szeptember 16., (15777/89).
} 
tulajdonjoggal a kérdéses föld felett? A vállalat, egy 1884-ben királyi rendelettel koncesszióba adott földet művelt, amelyet ugyan 1899-ben megvásárolt a koncesszió eredeti jogosultjától és bejegyeztetett az ingatlan nyilvántartásba, a koncessziós rendelet értelmében azonban a koncesszióval érintett földek bármikor visszavehetôk voltak a kedvezményezettek kárpótlása nélkül. Így amikor az állam 1978-ban létrehozott egy környezetvédelmi területet, az 1884-es rendeletre hivatkozva nem kárpótolta a céget, mondván, hogy nem kisajátítás történt, az állam csak a koncessziót vonta vissza. ${ }^{78}$

A panaszos felek az eljárás hossza miatt kérték a 6. cikk (1) bekezdés sérelmének megállapítását, valamint a hatékony jogorvoslathoz való jog (EJEE 13. cikk) sérelmének megállapítását, mert véleményük szerint az állami bíróságok nem biztosították azt. Kérték továbbá az első kiegészítő jegyzőkönyv sérelmének megállapítását és ehhez kapcsolódóan a 14. cikk sérelmét. ${ }^{79}$

A 6. és a 13. cikk sérelme kapcsán a Bíróság megállapította, hogy az eljárás elhúzódása nem azonos a jogorvoslathoz való hozzáférés hiányával: a panaszos felek többféle jogorvoslati eljárást is igénybe vehettek, a 13. cikk sérelme tehát nem állapítható meg. A Bíróság az eljárás elhúzódásának kérdését vizsgálva megállapította, hogy valóban sérült a 6 . cikk (1) bekezdése. ${ }^{80}$

Amint az említésre került, a tulajdonhoz való jog kérdése képezte az ügy lényegi magvát: az állam szerint a panaszos felek nem hivatkozhattak volna a tulajdonhoz való jog sérelmére, mivel soha nem is állt tulajdonukban a föld. Az állam nem kisajátította a földeket, mindössze visszavont egy koncessziót. Továbbá az állam szerint annak megállapítása, hogy egy jogviszony a belföldi jog szerint tulajdonnak minősül-e, nem az EJEB hatáskörébe tartozik. A panaszos felek ezzel szemben úgy vélték, hogy a tény miszerint a cég tulajdonjoga 1899-ben bejegyzésre került az ingatlan nyilvántartásba és az, hogy az eltelt évtizedek alatt a hatóságok is tulajdonosként kezelték a céget, bizonyítja a tulajdonjoguk fennálltát. ${ }^{81}$

A Bíróság álláspontja szerint a panaszos felek érvelése megállja a helyét, a földjük tulajdonnak minősül. ${ }^{82} \mathrm{Az}$ állam másik érve kapcsán - miszerint az EJEB nem rendelkezik hatáskörrel a tulajdonjog megítélését illetően - a Bíróság emlékeztetett, hogy az ítélkezési gyakorlata értelmében a tulajdonjog autonóm koncepció. ${ }^{83}$

Az EJEB ezt követôen meghatározta, hogy ebben az esetben a tulajdon békés élvezetének joga sérült, mivel a földet a vállalat bizonyos megszorításokkal tovább használhatta. A közérdek és az egyéni szabadságjogok közötti egyensúlyt illetően a Bíróság arra a következtetésre jutott, hogy tekintve az eljárás hosszas elhúzódását és azt a bizonytalanságot, amelyet a tulajdonosok voltak kénytelenek elviselni a tulajdonuk elvesztése és a kárpótlás kézhez kapását illetően, nem valósult meg a közérdek és az egyéni szabadságjogok közötti egyensúly. A Bíróság következésképpen megállapította a

\footnotetext{
78 Matos e Silva Lda. és mások k. Portugália 1996, 10-45.

79 Matos e Silva Lda. és mások k. Portugália 1996, 54.

80 Matos e Silva Lda. és mások k. Portugália 1996, 60-70.

81 Matos e Silva Lda. és mások k. Portugália 1996, 72-73, 77.

82 Matos e Silva Lda. és mások k. Portugália 1996, 74-75.

${ }^{83}$ EJEB, Gasus Dosier- und Fördertechnik GmbH k. Hollandia, 1995. február 23. (15375/89), 46.
} 
tulajdonhoz való jog sérelmét, a 14. cikk sérelmének külön vizsgálatát azonban nem tartotta szükségesnek. ${ }^{84}$

A Schelling k. Ausztria ügyben ${ }^{85}$ a panaszos fél egy vízáteresztőt szeretett volna elhelyezni a mezőgazdasági művelés alatt álló földjén, ehhez kérte az illetékes hatóságok hozzájárulását, melyek a szóbeli meghallgatást követően elutasították a kérelmét. A hazai igazságszolgáltatási fórumok előtt indított eljárások során a bíróságok rendre megtagadták a szóbeli eljárás tartását. A panaszos fél erre tekintettel kérte a 6. cikk (1) bekezdés sérelmének megállapítását. ${ }^{86}$

A Bíróság elismeri a nemzeti bíróságok jogát, hogy per és költséghatékonysági okokból tartózkodjanak a nyilvános tárgyalás tartásától, ${ }^{87}$ amennyiben a kérdés magas szintű műszaki vagy jogi tudást követel meg, ${ }^{88}$ amelynek a tisztázása a nyilvánosság helyett a szakértők feladata. A jelen ügyben azonban a Bíróság úgy ítélte meg, hogy nem áll fenn ilyen körülmény, így megállapította a 6 . cikk (1) bekezdés sérelmét. ${ }^{89}$

A Barcza és mások k. Magyarország ${ }^{90}$ ügyben a panaszos felek által birtokolt mezőgazdasági föld - egy, a 2002. december 16-án jogerőre emelkedett hatósági döntés értelmében - egy újonnan létrehozandó természetvédelmi terület részévé vált. A határozat rendelkezett a kisajátításról és egyben kötelezte a magyar államot, hogy tegyen kártérítési ajánlatot a földre. Az állam mulasztását követően a panaszos felek több ízben is eladásra ajánlották fel a földjeiket az állam részére, a közigazgatási szervek azonban nem éltek e lehetőséggel. Az ügyre végül az illetékes kormányhivatal tett pontot 2011-es határozatával, amelyben 39.170.000 forint, azaz $126.000 €$ összegben határozta meg a kártérítés összegét, amelyet a panaszos felek a következó évben kaptak kézhez. ${ }^{91}$

A panaszos felek arra hivatkozva kérték a tulajdonjoguk sérelmének megállapítását, hogy a közigazgatási hatóságok éveken keresztül nem rendezték a kisajátítás kérdését, megakadályozva őket a tulajdonjogukkal való rendelkezésben. Az állam vitatta a panaszos felek áldozati státuszát arra hivatkozva, hogy az ilyen tényállásokra a 6. cikk (1) bekezdése alkalmazandó, többek között azért, mert a jelen ügyben a panaszos felek részesültek kárpótlásban. Ellentétben a Brumăresc ${ }^{92}$ és Jasiūniene ${ }^{93}$ ügyekkel, ahol a panaszos felek a hazai eljárások során nem részesültek kártérítésben, erre hivatkozva az EJEB egyszerre állapította meg a tulajdonhoz és a

\footnotetext{
${ }^{84}$ Gasus Dosier- und Fördertechnik GmbH k. Hollandia 1995, 86-93, 96.

${ }^{85}$ EJEB, Schelling k. Ausztria, 2005. november 10., (55193/00).

86 Schelling k. Ausztria 2005, 8-25, 26.

${ }^{87}$ Lásd még a korábban említett Prischl k. Ausztria ügyet, amelyben a Bíróság a közigazgatási hatóságok által tartott szóbeli meghallgatást elégséges eljárási garanciának tartotta.

88 Továbbá: EJEB, Döry k. Svédország, 2002. November 12., (28394/95), 42-43; EJEB, Speil k. Ausztria, 2002. Szeptember 5 (42057/98); EJEB, Varela Assalino k. Portugália, 2002. Április 25. (64336/01); EJEB, Schuler-Zgraggen k. Svájc, 1993. június 24., (14518/89), 58.

${ }^{89}$ Schelling k. Ausztria 2005, 29-33.

${ }^{90}$ EJEB, Barcza és mások k. Magyarország, 2016. október 11., (50811/10).

${ }^{91}$ Barcza és mások k. Magyarország 2016, 5-22.

92 EJEB, Brumărescu k.Románia, 1999. október 28., (28342/95).

${ }_{93}$ EJEB, Jasiūnienè k. Litvánia, 2003. március 6., (41510/98).
} 
tisztességes eljáráshoz való jog sérelmét. ${ }^{94} \mathrm{Az}$ EJEB a kérdést illetően, a korábbi joggyakorlatát is figyelembe véve ${ }^{95}$ arra a következtetésre jutott, hogy önmagában az a tény, miszerint a panaszos felek részesültek kártérítésben, nem zárja ki a jogsérelem vizsgálatát; kivéve, ha a nemzeti bíróságok expressis verbis módon elismerték az Egyezményből eredő jogok sérelmét. Amely jelen ügyben nem történt meg, így az érdemi vizsgálat lefolytatásának nincs akadálya. ${ }^{96}$

A tulajdonjog elvonás természetét illetően a panaszos felek a tulajdonukkal való rendelkezés akadályozásában látták a jogsértést, az állam szerint de facto kisajátítás történt, az EJEB ezzel szemben az eset összes körülményét figyelembe véve arra jutott, hogy a tulajdonjoguk békés élvezetében akadályozták a panaszos feleket. A Bíróság ezt követően megvizsgálta, hogy sikerült-e igazságos egyensúlyt teremteni a közérdek és az egyént illető alapvető jogok között: tekintettel a bizonytalanságra, amelyet a panaszos felek évekig voltak kénytelenek elviselni, és amely alatt nem volt érdemi esélyük arra, hogy eladják az ingatlant vagy igazságos kompenzációban részesüljenek, az EJEB szerint megállapítható a tulajdonjog sérelme. ${ }^{97}$

A Tumeliai k. Litvánia ügyben ${ }^{98}$ szintén környezetvédelmi területté nyilvánították a panaszos felek földjét, amelynek folyományaként korlátozás alá esett a használati joguk. Az ügy tényállása akkor keletkezett, amikor a hatóságok elrendelték - a panaszos felek szerint legálisan, míg az állam szerint illegálisan - felépített nyaralójuk lebontását. ${ }^{99}$ A panaszos felek kérték a tulajdonhoz, valamint a tisztességes eljáráshoz való jog sérelmének megállapítását, utóbbit arra hivatkozva, hogy sérült a jogbiztonság elve. A Bíróság úgy ítélte meg, hogy az ügyet elegendő a tulajdonhoz való jog sérelme szempontjából vizsgálni, így a tisztességes eljáráshoz való jogot nem vizsgálta érdemben. ${ }^{100}$

Az állam pergátló kifogásként arra hivatkozott, hogy a panaszos felek nem rendelkeztek sem az első kiegészítő jegyzőkönyv szerinti tulajdonjoggal sem tulajdonjogra irányuló jogos elvárással, az ország alkotmánybíróságának joggyakorlata szerint ugyanis az illegálisan szerzett tulajdon nem élvezhet védelmet. Az EJEB az államétól eltérő következtetésre jutott: olvasatában a hazai jog alapján az illegálisan szerzett tulajdon is védelemben részesülhet. ${ }^{101}$

Azt, hogy a környezetvédelem napjainkban kiemelt fontossággal bír az EJEB már több korábbi ügyben ${ }^{102}$ is rögzítette, azonban a közérdek és az egyéni jogok

\footnotetext{
94 Barcza és mások k. Magyarország 2016, 28.

95 EJEB, Dalban k. Románia, 1999. szeptember 28. (28114/95) 44; EJEB, Konstantin Markin k. Oroszország, 2012.március 22. (30078/06), 82.

96 Barcza és mások k. Magyarország 2016, 31-38.

97 Barcza és mások k. Magyarország 2016, 39-48.

98 EJEB, Tumeliai K. Litvánia, 2018. január 9., (25545/14).

99 Tumeliai k. Litvánia 2018, 5-23.

100 Tumeliai k. Litvánia 2018, 58, 83-85.

101 Tumeliai k. Litvánia 2018, 59-66.

102 EJEB, Depalle k. Franciaország, 2010. március 29. (34044/02), 81; EJEB, Turgut és mások k. Törökország, 2008. július 8. (1411/03), 90; EJEB, Köktepe k. Törökország, 2008. július 22 (35785/03), 87; EJEB, Şatır k. Törökország, 2009. március 10. (36192/03), 33.
} 
tiszteletben tartása közötti egyensúly vizsgálata ez esetben sem mellőzhető. ${ }^{103}$ A jelen esetben a Bíróság szerint a panaszos fél tulajdonfeletti rendelkezési joga került korlátozásra, a hatóságok döntése törvényes volt és közérdekre - környezetvédelem irányult, az eldöntendő kérdés tehát az volt, hogy kellően arányos volt-e?104 E körben a Bíróság a korábbi ítélkezési gyakorlatára, ${ }^{105}$ utalva arra az álláspontra helyezkedett, hogy jelen ügyben az állami szervek korábbi hibáik korrigálása kirívóan nagy és aránytalan terhet rótt a panaszos felekre. A Bíróság megállapította a tulajdonhoz való jog sérelmét. 106

\section{4. Öröklés}

Az uniós országok közül több országban létezik előírás a mezőgazdasági földek minimális méretére vonatkozóan, amelyet egyéb megoldások mellett ${ }^{107}$ azzal biztosítanak, hogy több örökös esetén csak az egyik, általában a megfelelő végzettséggel rendelkező és/vagy rangidős viheti tovább a farmot, a többi örökös részének megváltása mellett. E törvényi előírások tulajdonképpen a tulajdonszerzést korlátozzák, amely az EJEB joggyakorlata értelmében ${ }^{108}$ nem élvez védelmet, ugyanakkor érdekfeszítő alkotmányjogi kérdéseket vet fel.109

Az Inze k. Ausztria ügyben ${ }^{110}$ a panaszos fél egy farmot örökölt többedmagával, majd az osztrák törvényeknek megfelelően - mint rangidős, és mint megfelelő végzettséggel rendelkező személy - kérte, hogy a többi örökös megváltása fejében a hatóságok őt jelöljék ki egyedüli örökösnek. A panaszos fél előadta továbbá, hogy a többi örökös nem rendelkezik megfelelő végzettséggel, amely kizáró ok mezőgazdasági föld öröklése szempontjából. A hatóságok az akkor hatályos törvények értelmében a panaszos kérelmét elutasították és törvénytelen gyermek státuszára, valamint a másik testvér alkalmasságát megállapító szakértői nyilatkozatra hivatkozva, az utóbbi javára ítéltek. Miután a bíróságok előtt sem járt sikerrel, a panaszos fél belegyezett egy számára előnytelen alkuba. ${ }^{111}$

\footnotetext{
103 EJEB, Vistinš és Perepjolkins k. Litvánia, 2012. október 25. (71243/01) 109.

104 Tumeliai k. Litvánia 2018, 73-76.

105 EJEB, Romankevič k. Litvánia, 2014. december 2. (25747/07), 38-39; EJEB, Albergas és Arlauskas k. Litvánia, 2014. május 27. (17978/05) 59.

106 Tumeliai k. Litvánia 2018, 77, 80, 82.

107 Bányai Krisztina: A Földszerzés korlátozása Nyugat-Európában. Miskolci Jogi Szemle, 2017/2 különszám, 71-80.

108 Tekintve, hogy az EJEE az 1949. évi XX törvénnyel és az Alaptörvénnyel ellentétben nem nevesíti az örökléshez való jogot, az EJEB esetjogában az örökléshez való jog sem jelenik meg önállósan, ám találni olyan példákat, ahol örökléshez való jog tartalmát is érintette a testület, valamely az Egyezmény által védelemben részesített joggal összefüggésben. Lásd: EJEB, Marckx k. Belgium, 1979. június 13., (6833/74).

109 A korábban hivatkozott 5/2016 AB (III.1.) határozatban rögzített többségi vélemény és Sulyok Tamás párhuzamos indokolása is foglalkozott a tulajdonhoz és az örökléshez való jog közötti párhuzammal.

${ }^{110}$ EJEB, Inze k. Ausztria, 1987. október 28., (8695/79).

111 Inze k. Ausztria 1987, 8-24, 25.
} 
A panaszos fél szerint diszkrimináció érte, amikor a törvénytelen gyermek státusza miatt nem örökölhette meg édesanyja földjét, erre hivatkozva kérte az EJEE 14, a hátrányos megkülönböztetést tiltó cikkének és a tulajdonhoz való jog sérelmének megállapítását. ${ }^{112}$

Az állam vitatta a panaszos fél áldozat státuszát, tekintve, hogy részesült kárpótlásban. Az EJEB azonban a panaszos féllel és a Bizottsággal együtt arra az álláspontra helyezkedett, hogy a panaszos fél nem volt megfelelő alku pozícióban, amikor az említett megállapodást aláírta, amelynek így tulajdonképpen kényszerből tett eleget. ${ }^{113} \mathrm{Az}$ állam vitatta továbbá a panaszos fél tulajdonjogát: álláspontja szerint a Marckx-ügyhö̈.114 hasonlóan nem volt sem valódi tulajdonjoga, sem arra irányuló jogos elvárása, ${ }^{115}$ következésképpen jogsérelem sem következhetett be. Az EJEB szerint ugyanakkor jelen ügyben - ellentétben az említett üggyel, ahol a panaszos fél absztrakt módon ${ }^{116}$ hivatkozott a jogsérelemre - a panaszos fél, mint az elhunyt örököse, ténylegesen rendelkezett jogos elvárással az öröklési jogviszony révén. ${ }^{117}$

Amint arra a Bíróság rámutatott, a korábbi ítélkezési gyakorlata alapján abban az esetben áll fenn a 14. cikk sérelme, ha a különbségtétel nem objektív és ésszerūen nem igazolható, azaz nem törvényes célra irányul és nem arányos. E téren az államok széles mérlegelési jogkörrel rendelkeznek, amelynek terjedelmét az adott ügy összes körülménye határozza meg. ${ }^{118}$ Ugyanakkor a Bíróság emlékeztetett rá, hogy az Egyezmény egy élő intézmény, amelyet az aktuális társadalmi folyamatok tükrében kell értelmezni. Erre figyelemmel, jelen esetben a Bíróság nem fogadta el az állam idejétmúlt - érvelését azt illetően, hogy a vidéki népesség esetén miért kell előnyben részesíteni a törvényes gyermeket a törvénytelen gyermekkel szemben. Következésképpen megállapítható a 14. cikk és azzal összefüggésben az első kiegészítő jegyzőkönyv első cikkének sérelme. ${ }^{119}$

Az Osinger k. Ausztria ügyben ${ }^{120}$ a panaszos fél és a másik testvér is kérte, hogy ôt jelöljék ki az örökséget képező farm örököseként. ${ }^{121}$ A panaszos fél arra hivatkozva kérte a tisztességes eljáráshoz való jog sérelmének megállapítását, hogy az osztrák bíróságok elutasították a nyilvános tárgyalás tartására vonatkozó kérelmét. ${ }^{122}$

Az állam ezzel kapcsolatban előadta, hogy az örökléssel kapcsolatos ügyekben a nyilvános meghallgatás mellőzése az EJEE 8. cikke által garantált a „Magán- és családi élet tiszteletben tartásához való jog" tiszteletben tartása miatt szükséges, az érintett

\footnotetext{
112 Inze k. Ausztria 1987, 35.

113 Inze k. Ausztria 1987, 30-34.

114 Marckx k. Belgium 1979.

${ }^{115}$ Lásd még: EJEB, AGOSI k. Egyesült Királyság, 1986. október 24., (9118/80), 48.

116 A panaszos fél azt kifogásolta, hogy törvénytelen gyermeke - majdani - öröklési jogai törvényileg korlátozás alá esnek.

117 Inze k. Ausztria 1987, 37, 38.

118 Lásd: EJEB, Lithgow és mások, 1986. július 8. (9006/80; 9262/81; 9263/81; 9265/81; 9266/81; 9313/81; 9405/81) 177.

119 Inze k. Ausztria 1987, 41-45.

${ }^{120}$ EJEB, Osinger k. Ausztria, 2005. március 24., (54645/00).

121 Osinger k. Ausztria 2005, 8-35.

122 Osinger k. Ausztria 2005, 38.
} 
személyek családi és pénzügyi helyzete ugyanis nem tartozik a nyilvánosságra. Utalva továbbá az EJEB korábbi joggyakorlatára ${ }^{123}$ az állam úgy vélte, hogy a pusztán technikai jellegű kérdések eldöntése - mint, amelyen a jelen farmra vonatkozó öröklési szabályok - esetén mellőzhető a tárgyalás tartása. Az EJEB ezen érv jogosságának elismerése mellett emlékeztetett rá, hogy az ítélkezési gyakorlatából ${ }^{124}$ következően a nyilvánosság a tisztességes eljárás egyik fó pillére, amely biztosítja a társadalmi kontrollt az állami szervek eljárása felett. Tény, hogy a Bíróság joggyakorlata elismeri az államok azon jogát, hogy egyes ügycsoportokat ${ }^{125}$ mentesítsenek bizonyos eljárási szabályok alól, az EJEB ugyanakkor ilyen esetekben is fenntartja a jogot, ${ }^{126}$ hogy felülvizsgálja ezen állami szabályokat. Jelen ügyben az EJEB nem találta meggyőzőnek az állam érvelését, miszerint a Schuler-Zgraggen k. Svájc ügyhöz.127 hasonlóan pusztán technikai kérdéseket kellett volna tisztázni, és megállapította a tisztességes eljáráshoz való jog sérelmét a nyilvános tárgyalás mellözése miatt. ${ }^{128}$

\section{3. Összefoglaló}

A szerző, jelen írásában arra kereste a választ, hogy a tisztességes eljárás és a hatékony jogorvoslathoz való jog szempontjából, valamint a tulajdonjog sérelme szempontjából mennyire EJEE konform a Fétv. 108. paragrafusa.

Az EJEB tisztességes eljárással összefüggő állandó ítélkezési gyakorlata értelmében az államoknak széles mérlegelési jogköre van azt illetően, hogy a bírói felülvizsgálat milyen szabályok szerint zajlik, milyen bizonyítékok benyújtását követelik meg. A hazai bíróságok előtti eljárásokkal kapcsolatban a földrendezéssel és környezetvédelemmel kapcsolatos ügyekben gyakori panasz volt a szóbeli meghallgatás mellőzése. Az EJEB emlékeztetett rá, hogy az ítélkezési gyakorlata értelmében - többek között a Stallinger és Kuso ügyben foglaltaknak megfelelően - a földbizottságok bíróságnak számítanak és nyilvános az eljárásuk, következésképpen a rendes bíróságok megtagadhatják a nyilvános meghallgatás tartását. A szóbeli meghallgatás mellőzhető továbbá abban az esetben is, ha a kérdés megválaszolása magas szintű műszaki, technikai szakértői tudást követel meg vagy bonyolult jogi kérdést szükséges tisztázni, ahogyan azt a környezetvédelmi ügyek között tárgyalt Schelling ügyben is rögzítette a Bíróság. Az egyes ügyek külön-külön történő bírói felülvizsgálatát kizáró szabályozás ugyanakkor, ahogyan az a Pyrantiená ügyben is rögzítésre került, ellentétes az EJEE rendelkezéseivel.

${ }^{123}$ EJEB, Varela Assalino k. Portugália, 2002. április 25., (643369/01).

${ }^{124}$ EJEB, Sutter k. Svájc, 1984. február 22. (8209/78), 26.

$125 \mathrm{Az}$ említett ügyben a fokozottan veszélyes bűnözők esetén vélte kizárhatónak a nyilvánosságot arra hivatkozva, hogy az államra aránytalanul nagy terhet róna a rend fenntartása a nyilvánosság biztosítása esetén. - EJEB, Campbell és Fell k. Egyesült Királyság, 1984. június 28. (7819/77 7878/77), 87-88.

${ }^{126}$ EJEB, Riepan k. Ausztria, 2000. november 14. (35115/97), 34.

127 EJEB, Schuler-Zgraggen k. Svájc, 1993. június 24. (14518/89).

128 Osinger k. Ausztria 2005, 39, 43-44, 47, 49, 51, 53. 
A földrendezéssel kapcsolatos ügyekben jellemző másik panasz az ésszerú időn túli mértékben elhúzódó eljárások miatt bekövetkező jogsérelem. Az eljárások nem egy esetben akár egy évtizedig vagy tovább is elhúzódnak. Az eljárás hosszának számítását illetően a Bíróság, joggyakorlatának megfelelően három szempontot vizsgál: (i) az ügy komplexitását; (ii) a panaszos fél és a (iii) hatóságok magatartását. A földrendezéssel kapcsolatos ügyek jellemzően komplexek és ebből kifolyólag hosszan elhúzódnak, a Bíróság azonban a legtöbb esetben megállapította az ügyek ésszerūtlen ideig történő elhúzódását.

A fentieket összefoglalva elmondható, hogy a földrendezéssel kapcsolatos ügyekben a panaszos felek jellemzően a tisztességes eljáráshoz való joguk sérelmének megállapítását kérték, a tulajdonhoz való jog sérelmét csak másodlagosan - jellemzően a kapott kártérítés elégtelen voltára hivatkozással -, ráadásul maga az EJEB több esetben feleslegesnek ítélte a tulajdonhoz való jog sérelmének vizsgálatát. Előfordult ugyanakkor olyan ügy is, ahol az eljárás hosszát nem a hatodik cikk sérelme, hanem a tulajdonjog kapcsán vizsgálta, az EJEB ítélkezési gyakorlata - Airey ügy - alapján ugyanis egy-egy ténybeli elem az egyezmény és kiegészítő jegyzőkönyveinek több rendelkezését is sértheti, azaz felcserélhetők egymással.

$\mathrm{Az}$ EJEB tulajdonelvonással kapcsolatos állandó ítélkezési gyakorlata, amely elsősorban a kárpótlási és az öröklési ügyekben került előtérbe megköveteli, hogy a tulajdontól való megfosztás törvényen alapuljon, törvényes célra irányuljon és arányos legyen. Törvényes cél példának okáért a közérdek, amely terén az állami törvényhozás a James-ügyben foglaltaknak megfelelően széles mérlegelési jogkörrel rendelkezik, sőt mi több, a volt keleti blokk országai az átmeneti időszakban még a szokásosnál is szélesebb mérlegelési jogkört élveztek, amint azt - többek között - a Jahn-ügyben is megfogalmazta a Bíróság.

A közérdek szükségszerūen tág fogalom, beletartozhat többek között az állam korábbi hibájának korrigálása, példának okáért a második világháborút követô államosítások kárvallottjainak kárpótlása. Ez azonban nem vezethet oda, hogy a kárpótlás révén jóhiszemű harmadik felek látják kárát az állam intézkedésének. A Bíróság ítélkezési gyakorlata alapján - ahogyan az a Pincová és Pinc ügyben is rögzítésre került - a régi sérelmek orvoslása nem vezethet új sérelmek keletkezéshez.

Közérdek lehet továbbá a mezőgazdasági földek elaprózódását gátoló szabályozás, amelynek értelmében a mezőgazdasági földeket csak az egyik örökös viheti tovább; az, aki megfelelő végzettséggel rendezik és/vagy rangidős. Az osztrák törvények tulajdonképpen korlátozzák azon örökösök tulajdonszerzését, akik nem rendelkeznek a föld megműveléséhez szükséges képesítéssel. E szabályozás EJEE konform, feltéve, hogy a szabályozás nem diszkriminatív, mint az Inze ügyben, illetve betartják a tisztességes eljárás garanciáit, amint azt az Osinger-ügyben rögzítette a Bíróság.

A tulajdon elvonás jogszerűségének vizsgálata során megkövetelt arányosság kapcsán kiemelt szerepe van a panaszos felek által kapott kártérítés mértékének, amelynek közelítenie kell az elveszett tulajdon piaci értékét, ugyanakkor a teljes mértékű kárpótlás nem várható el minden esetben, amely a Pincová ügyben szintén rögzítésre került.

A joggyakorlat tanulmányozását követően a megválaszolandó kérdés az, hogy a magyar szabályozás, jelesül a Fétv. 108 §-a megfelel-e az EJEE által támasztott 
követelményeknek? Az írás szerzője szerint azt a választ kell adni, hogy a tisztességes eljárás követelménye felől vizsgálva bizonyosan ellentétes azokkal, míg a tulajdonjog védelme irányából vizsgálva - a bevezetésben rögzített feltevést elfogadva - minden valószínűség szerint ellentétes.

A tisztességes eljárás illetöen azáltal, hogy a magyar szabályozás kizárja az ügyek egyesével történő bírói felülvizsgálatát és törvényi vélelemre alapozva - amely szerint minden egyes haszonélvezeti jogot a törvények kizárásának céljával kötöttek meg a múltban -, ex lege megszünteti azokat - az állami törvényhozás széles mérlegelési jogköre ellenére is -, ellentétes a tisztességes eljáráshoz és a hatékony jogorvoslathoz való joggal, amint azt többek között a Pyrantiená ügyben is rögzítésre került.

A tulajdonhoz való jogot illetôen: vizsgálandó, hogy a hatóságok eljárása törvényen alapszik-e, törvényes célra, vagyis közérdekre irányul-e és arányos-e. Az első kérdésre, miszerint törvény alapján történik-e a válasz nyilvánvalóan igen, a másik kettốre azonban nem ilyen egyértelmű a válasz. Bár a törvényellenesen, a törvény kijátszása céljából kötött haszonélvezeti szerződések megszüntetése törvényes célra, közérdekre irányulónak tekinthetô, a választott eszköz aránytalan az elérendő célhoz képest tekintve, hogy olyan szerződő feleket is érint, akik jóhiszeműen jártak el. Következésképpen a múltbéli sérelmek orvosolása új sérelmek keletkezéséhez vezet, amely a Pincová ügyben rögzítettek szerint ellentétes az EJEE rendelkezéseivel. Az is említést érdemel továbbá, hogy a Tumeliai ügyben az EJEB arra az álláspontra helyezkedett, hogy az illegálisan szerzett tulajdonjog is védelemben részesülhet. Ily módon akár a törvények kijátszása céljából kötött haszonélvezeti jog is védelemben részesülhet. - Akkor is, ha az szembemegy a természetes igazságérzettel.

Tovább folytatva az eszmefuttatást, az arányosság szempontjából vizsgálandó, hogy a kapott kártérítés értéke hogyan viszonyul az elveszett tulajdon piaci értékéhez, ahogy azt a Pincová ügyben is rögzítette az EJEB. Az Alkotmánybíróság a már korábban említett a 25/2015. (VII.21.) sz. határozatában megállapította, Alaptörvény ellenes az a helyzet, amelyben a törvényhozó nem rendelkezett a Ptk. szabályai által nem szabályozott elszámolási viszonyok rendezéséről. Előfordulhat tehát olyan helyzet, hogy a jóhiszeműen kötött haszonélvezeti szerződések részes felei nem tudnak teljes körūen elszámolni, és az államtól sem várhatnak kártérítést.

Ugyanakkor a fentiek ellenére azt sem szabad elfelejteni, hogy a földrendezéssel kapcsolatos ügyekben az EJEB a tulajdonjog sérelmének vizsgálatát - amennyiben a felek kérték - vagy elutasította arra hivatkozva, hogy az osztrák törvények értelmében a panaszos felek nem rendelkeztek az egyezmény alapján védelemben részesítendő joggal, mint a Prischl ügyben. Vagy a tulajdonjog sérelmét is az eljárás hosszának szempontjából vizsgálta, ahogyan az Erkner ügyben esetleg egyáltalán nem vizsgálta, mert úgy vélte, hogy a hatodik cikk sérelmének megállapítása elegendő jóvátétel, ahogyan az Ortner ügyben.

A kérdés tehát nyitott, hogy az EJEB vizsgálná-e az esetlegesen elé kerülő magyar ügyeket a tulajdonjog sérelme szempontjából, avagy csak a tisztességes eljárás sérelmét? 